\title{
BEHAVIORAL ECOLOGY OF AMERICAN PIKAS (OCHOTONA PRINCEPS) AT MONO CRATERS, CALIFORNIA: LIVING ON THE EDGE
}

\author{
Andrew T. Smith ${ }^{1}$ John D. Nagy 2,3 , and Constance I. Millar ${ }^{4}$
}

AвstRaCT.-The behavioral ecology of the American pika (Ochotona princeps) was investigated at a relatively hot south-facing, low-elevation site in the Mono Craters, California, a habitat quite different from the upper montane regions more typically inhabited by this species and where most prior investigations have been conducted. Mono Craters pikas exhibited a behavioral profile that contrasted significantly with that of pikas found in upper montane regions. Mono Craters pikas were less surface active than pikas in studies at high-elevation sites, although their rate of short-call vocalizations was similar. Mono Craters pikas did not exhibit typical foraging behavior: they fed and collected hay at significantly reduced rates, and did not construct large central-place hay piles. Social behaviors (conspecific aggression, social tolerance, avoidance) were infrequent compared with data from prior studies in upper montane environments. The Mono Craters site appears to be one of the warmest localities in which pikas have been observed. Recorded talus surface temperatures consistently exceeded $30{ }^{\circ} \mathrm{C}$, and temperatures $>40{ }^{\circ} \mathrm{C}$ were commonly recorded. In contrast, temperatures measured in the matrix of the talus were consistently cooler, and the apparent insulating effect of talus, as measured by the difference between surface and matrix temperatures, was typically most pronounced on the hottest days. Although pika activity was most frequent in early morning, late afternoon, and at night, pikas were also active during the hottest part of the day, presumably because of their ability to behaviorally thermoregulate by retreating into the cooler talus matrix. Data on populations of pikas which inhabit marginal sites can help us understand how pikas and other montane animals might respond in a world of climate change so that we may more effectively plan for their conservation.

RESUMEN.-La ecología del comportamiento de la pika americana (Ochotona princeps) fue investigado en un sitio de baja elevación, relativamente caliente y orientado hacía el sur en Mono Craters, California. Es un hábitat muy diferente de las regiones de alta montaña más típicamente habitadas por esta especie y donde se han realizado la mayoría de las investigaciones anteriores. Las pikas de Mono Craters exhibian un comportamiento que contrastaba significativamente con los de pikas encontradas en regiones de alta montaña. Las pikas de Mono Craters eran menos activas en la superficie que las pikas en estudios en sitios de altura, aunque su rango de vocalizaciones cortas fue similar. Las pikas de Mono Craters no mostraron un comportamiento típico de forrajeo: se observaron alimentándose y colectando el heno a una tasa reducida significativa y no construian grandes pilas centrales de heno. Los comportamientos sociales (agresión conespecíficas, tolerancia social, evitación) fueron poco frecuentes en comparación con estudios anteriores en ambientes de alta montaña. El sitio de Mono Craters parece ser una de las localidades más cálidas donde se han observado las pikas. Las temperaturas registradas de la superficie del talud excedió de manera consistente $30{ }^{\circ} \mathrm{C}$, y las temperaturas $>40{ }^{\circ} \mathrm{C}$ se registraron comúnmente. Por el contrario, las temperaturas medidas en la matriz del talud fueron consistentemente más frescas, y el aparente efecto aislante del talud, medido por la diferencia entre las temperaturas de superficie y de la matriz, fue típicamente más pronunciadas en los días más calurosos. Aunque la actividad pika era más frecuente en la mañana, en la tarde y por la noche las pikas también estaban activos durante la parte más caliente del día, probablemente debido a su capacidad para regular la temperatura de comportamiento retirándose a la matriz de talud más fresco. Datos sobre las poblaciones de las pikas que habitan en sitios marginales pueden ayudar a entender cómo las pikas y otros animales montanos podrían responder en un mundo de cambio climático, de manera que podamos planificar eficazmente para su conservación.

Our understanding of the behavioral ecology of most species originates from investigations conducted near the core of their distributional range. Here population sizes are likely to be the largest and most robust, and the architecture of responses should best typify how a species responds to its optimal envi- ronment. In contrast, range margins have long been recognized for their potential evolutionary significance (Brown 1971). In a world of anthropogenic climate change and associated global warming, it is increasingly instructive to study how animals behave at the edge of their species' range. In particular, interior

\footnotetext{
${ }^{1}$ School of Life Sciences, Arizona State University, Tempe, AZ 85287-4501. E-mail: a.smith@asu.edu

${ }^{2}$ Department of Life Sciences, Scottsdale Community College, Scottsdale, AZ 85250

${ }^{3}$ School of Mathematical and Statistical Sciences, Arizona State University, Tempe, AZ 85287-1804.

${ }^{4}$ USDA Forest Service, Pacific Southwest Research Station, Albany, CA 94710.
} 
margins - that is, sites within the primary species range but at environmental limits - can elucidate climatic variation and behavioral adaptability and vulnerability relative to populations in adjacent optimal habitat conditions (Bridle and Vines 2007, Sexton et al. 2009, Varner et al. 2016). What mechanisms do species possess that allow them to be resilient and to persist when confronted with suboptimal conditions? What specific factors or stresses may play the greatest role in leading to extirpation of these populations? We need to understand the tensions found in marginal populations so that we can better understand population responses to climate change and, as necessary, manage for population persistence.

Studies of the American pika (Ochotona princeps) have followed the typical pattern outlined above; nearly all detailed investigations of the species' behavioral ecology have been conducted in high-elevation habitats that are most representative of the species' natural history (Krear 1965, Sharp 1973, Tapper 1973, Kawamichi 1976, Svendsen 1979, Smith and Ivins 1983a, 1984, Massing 2012, Varner et al. 2016). Some long-term studies, however, have been conducted at lower elevations, which are warmer and represent marginal situations for pikas (Severaid 1955, Smith 1974a, Peacock and Smith 1997, Massing 2012, Varner et al. 2016), although none of these efforts attempted to investigate the full behavioral profile of pikas. Instead, most of the recent literature on American pikas occupying marginal habitats has been characterized by short-term surveys that have not addressed aspects of the behavioral ecology of resident animals (Beever et al. 2003, 2008, 2010, 2011, Millar and Westfall 2010, Rodhouse et al. 2010, Erb et al. 2011, Manning and Hagar 2011, Wilkening et al. 2011, Collins and Bauman 2012, Stewart and Wright 2012, Jeffress et al. 2013, Millar et al. 2013a, Rowe et al. 2014, Shinderman 2015, Stewart et al. 2015, Schwalm et al. 2016).

The American pika is considered a sentinel species for the effects of climate change on a montane mammal (Smith et al. 2004, Beever and Wilkening 2011, Ray et al. 2012) because pikas possess many characteristics that could precipitate population reductions or local extirpations should temperatures continue to increase dramatically (Parmesan 2006, Guralnick 2007, Sgrò et al. 2011):
(1) Pikas have a high resting body temperature $\left(40.6{ }^{\circ} \mathrm{C}\right)$, which is within only a few degrees of their upper lethal level $\left(43.0{ }^{\circ} \mathrm{C}\right.$; MacArthur and Wang 1973);

(2) Because of their sensitivity to warm temperatures, pikas behaviorally avoid activity during midday when temperatures are warmest (Severaid 1955, Smith 1974a, MacArthur and Wang 1974, Otto et al. 2015);

(3) Pikas are nonhibernating and rely on snow cover for thermal insulation in winter; diminishing snowpack may expose them to acute cold temperatures (Smith 1978, Ray et al. 2012);

(4) Pikas are individually territorial on a generally nonproductive habitat (talus) bordering vegetative habitat. With the wide spacing between individuals, local population density is low and small habitat patches of talus contain a limited number of animals (Smith 1974b, Smith and Ivins 1984, Smith 1987). As a result, habitat patches are subject to stochastic extinction events (Smith 1974b, Smith and Gilpin 1997, Moilanen et al. 1998, Smith and Nagy 2015);

(5) Pikas characteristically are poor dispersers. Once an animal establishes a territory, it is unlikely to disperse during its lifetime, and juvenile pikas have limited dispersal capabilities (Smith and Ivins 1983a, Smith 1987). Juvenile dispersal may be impeded due to social dynamics on saturated habitat in which all territories are occupied (Smith and Ivins 1983a), and they face an uncertain fate when they leave their natal talus in an attempt to find vacant talus elsewhere. While dispersing, juveniles are unable to behaviorally thermoregulate by retreating into the cool interstices offered by talus habitat; thus, successful dispersal appears to be related to ambient temperature (Smith 1974a, 1987, Peacock and Smith 1997). Therefore, at low elevations, a distance of a few hundred meters may pose a barrier to dispersal (Smith 1974b, Smith and Gilpin 1997, Smith and Nagy 2015), whereas contemporary maximum reported dispersal distances at higher elevations range between 2 and 3 km (Tapper 1973, Peacock 1997). As regional temperatures increase, excessively warm ground surfaces between adjacent taluses could be a key limiting factor for dispersal (Millar et al. 2016);

(6) Annual reproductive capacity of American pikas is low. All adult females breed and produce 2 small litters per season (average litter size is approximately 3; Millar 1973, 1974, Smith 1978), though only one litter is successfully weaned per season (Smith and 


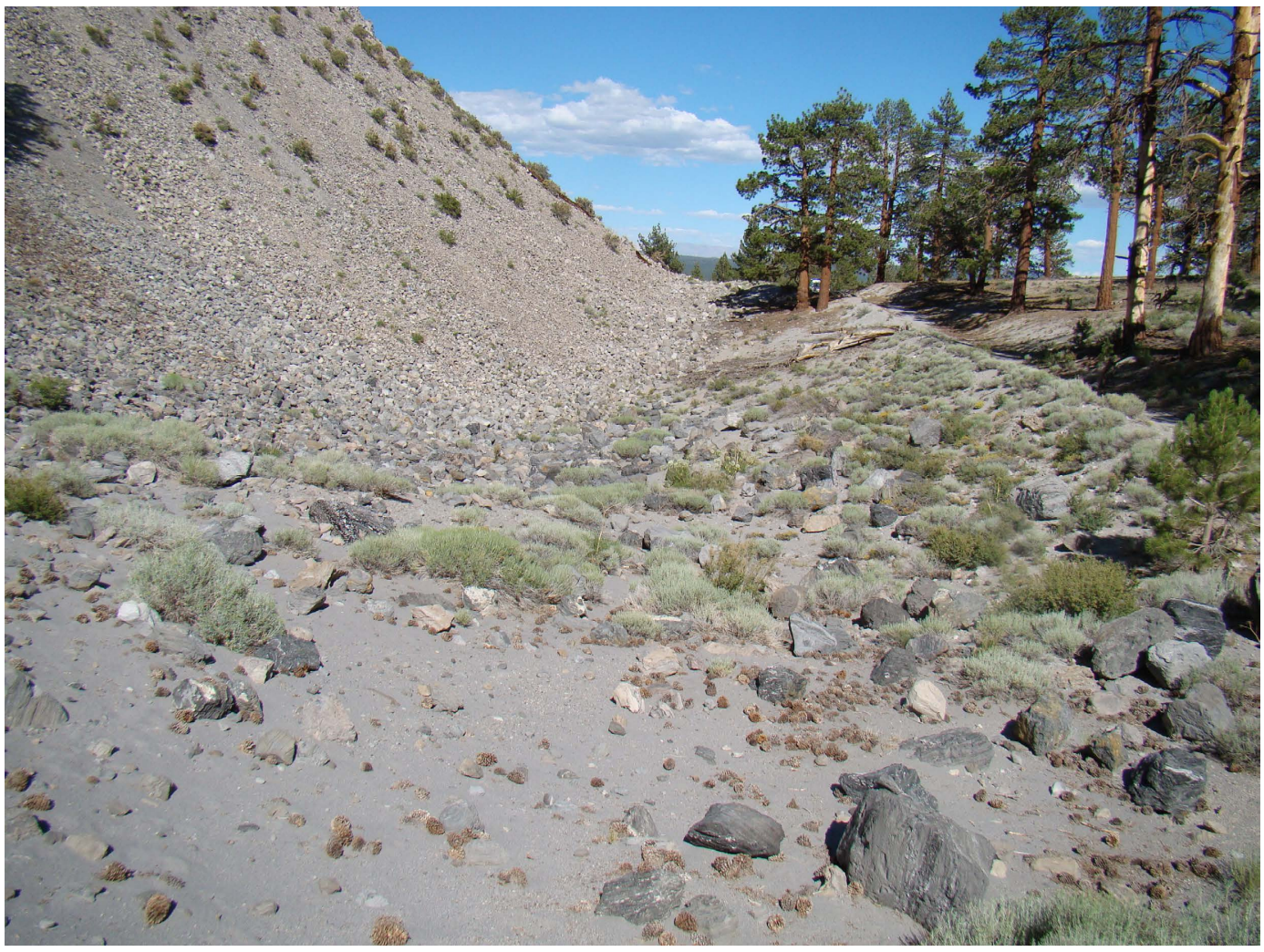

Fig. 1. Vista of the Mono Craters (South Coulee) study area, Mono County, California, looking east showing the steep talus and sparse vegetation in both the forefield and on the talus.

Ivins 1983b), and throughout their range, most females wean only 2 young per year (Millar 1973, 1974, Smith 1978).

These features (temperature sensitivity, low density, low dispersal capability, and low rate of reproduction) interact to make pikas vulnerable to population extirpation and, perhaps, to regional extinction. One factor that works in the opposite direction is that, for a small mammal, pikas can be relatively long-lived; some individuals may live to the age of 6 (or even 9; C. Ray personal communication). Any population likely comprises several 3- or 4-year-old animals (Millar and Zwickel 1972a, Smith 1978), thus reducing the probability of random extirpation of populations.

Pikas engage in distinctly different behaviors over the course of the year, exposing them to seasonal changes in temperature during key phases of their life stages (Smith and Ivins 1984). In addition, many behaviors occur earlier in populations found at lower, warmer localities than in populations living at higher elevations (Smith 1974a). Thus, ambient weather and regional climatic patterns already influence pikas over the course of the season such that they may be able to deal with warming climates in the future.

Here we present a detailed analysis of the behavioral ecology of a population of American pikas occupying an interior marginal habitat site (low elevation, south-facing, hot, dry) in the Mono Craters, Mono County, California. Compared with typical habitat of high-elevation pika populations, this site is nearly barren of vegetation (Fig. 1, Supplementary Material 1). To better understand how these animals have avoided population extirpation in this marginal habitat, we sought to evaluate the relationship between the environment and thermal regime at the site and identify features of pika biology that have allowed pikas to persist there. The Mono Craters site acts as a surrogate for conditions that higher elevations might experience in a 


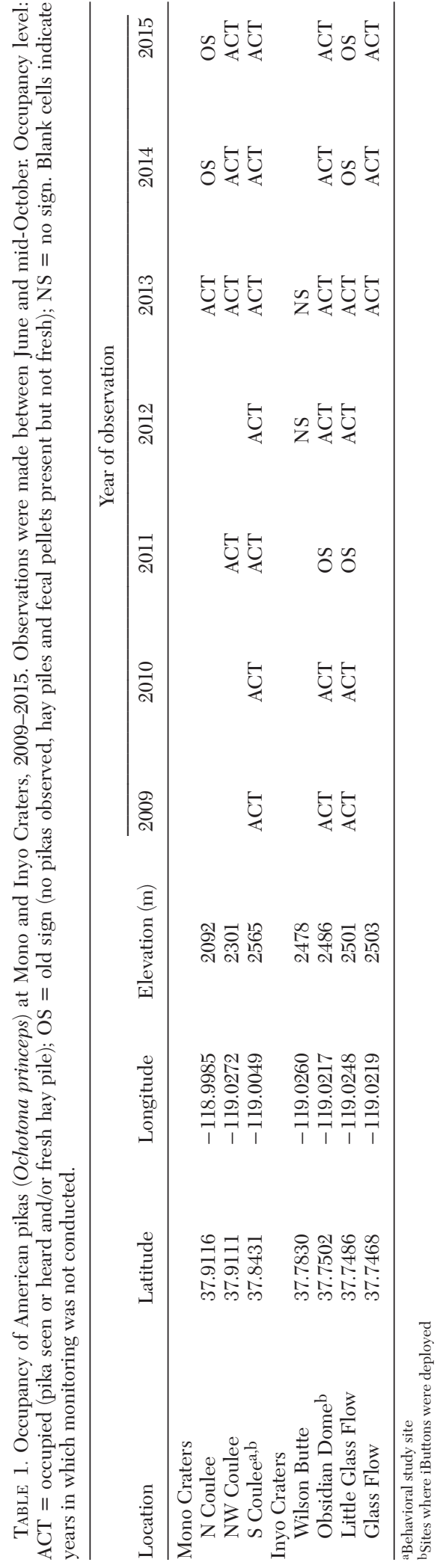

future of continued global warming and thereby can provide insight into the ability of pikas to alter their activity according to temperature. Data on populations that survive and reproduce in interior marginal sites will help us understand the future responses of pikas and other montane animals in a world of climate change and then plan for their conservation.

\section{Methods \\ Study Area}

The study area comprised a south-facing slope on South Coulee near the southern end of the Mono Craters (hereafter referred to as the South Coulee site; Table 1). The Mono Craters form an isolated 13-km-long string of gray rhyolite obsidian and pumice domes that formed roughly south to north. The northernmost dome, Panum Crater, erupted between 1350 and $1445 \mathrm{CE}$, whereas the southern domes, including the one on which we worked, formed 35,000 years ago (geological details in Loney 1968, Hill 2006). Currently occupied pika populations extend from the South Coulee site to near the northern end of the range (Millar et al. 2013a; Table 1). The route by which pikas in all likelihood traveled to colonize the Mono Craters extends from the Sierra Nevada crest in the west through the Inyo Craters (latest eruption in $1350 \mathrm{CE}$; Millar et al. 2006) and through Wilson Butte (1350 years old). The distance of the most likely dispersal path from the Mono Craters to the nearest known occupied site (Inyo Craters) is $10 \mathrm{~km}$. The South Coulee site is located near the low-elevation margin for pikas in the region, $2565 \mathrm{~m}$ (at the foot of the talus; Table 1), and extends west to east approximately $300 \mathrm{~m}$. The talus occupied by pikas cascades at near the angle of repose along most of this reach (Loney 1968), and the forefield largely comprises barren patches of rhyolite sand punctuated by occasional obsidian or pumice boulders and sparse vegetation (Fig. 1, Supplementary Material 1). The talus also contains widely separated shrubs. Beyond the forefield to the south is an open forest dominated by old-growth Jeffrey pine (Pinus jeffreyi).

An unusual aspect of the study site is that it sits on top of an extensive bed of permafrost (Loney 1968). At one locality we noted a small lacuna in the rhyolite sand supported by small rocks through which a current of cooler air 
flows out to the surface. We recorded a shade temperature of $32.2{ }^{\circ} \mathrm{C}$ at $12: 18$ on 10 July 2013 in the shade of an Ericameria nauseosa shrub $<1 \mathrm{~m}$ away from the entrance to this drainage, whereas $10 \mathrm{~cm}$ inside this hole the air temperature was only $20.0^{\circ} \mathrm{C}$ (Supplementary Material 2A). A FLIR (forward-looking infrared) camera image of this site (Supplementary Material 2B) taken at 11:40 on 31 August 2013 shows the stark contrast between surface ambient temperature and the current of cooler air emanating from this hole.

The study area was also occupied during the day by golden-mantled ground squirrels (Callospermophilus lateralis), as well as lodgepole chipmunks (Tamias speciosus) and least chipmunks (Tamius minimus) that routinely crisscrossed the talus. Occasionally a Douglas's squirrel (Tamiasciurus douglasii) ascended the talus. Long-tailed weasels (Mustela frenata) regularly crossed the study area and generally elicited alarm calls by the resident pikas (Ivins and Smith 1983). Soaring or large flying birds that also triggered alarm calls when overhead included Cooper's Hawks (Accipiter cooperii), Northern Harriers (Circus cyaneus), Red-tailed Hawks (Buteo jamaicensis), Peregrine Falcons (Falco peregrinus), Common Ravens (Corvus corax), and Clark's Nutcrackers (Nucifraga columbiana).

\section{Temperature Analyses}

We recorded ambient temperatures using Maxim iButton mini-thermochrons (http:// www.maximintegrated.com/en/products/ comms/iButton/DS1921G.html). Our protocol for deployment of the thermochrons paralleled the methods outlined in Millar et al. (2013b, 2014, 2016). Thermochrons were protected from direct solar radiation and animal activity (chewing) in 2 ways: each was wrapped in wire mesh and the wire mesh package was inserted into white PVC-T fittings with 3 approximately 2 -cm-diameter openings that allowed sufficient airflow to each instrument. Depending on the context of deployment, each iButton package was either secured to a rock, shrub, or tree with wire or attached to a tree branch, which was then used to insert the package into the talus matrix. All iButton packages were situated in shaded locations.

Thermochrons were used in 2 ways. As part of a larger multiyear study (hereafter called the longitudinal study), C.I. Millar has been monitoring temperatures in environments occupied by pikas at 37 locations in the western Great Basin (Millar et al. 2016). Data sets from 2 locations of that study, the Mono and Inyo Craters, are included here to provide a longterm context for the behavioral study. The Mono Craters iButtons for the longitudinal study were located on a rocky outlying berm just west of the South Coulee site; the talus below the hay pile was shallower than the main slope, and the aspect was flat. The Inyo Craters iButtons were placed on a southfacing aspect at the base of the main talus slope at Obsidian Dome. At each location, paired iButtons were deployed from October 2009 to October 2014 on the surface of a hay pile (active at the time of deployment) and about $0.5-1 \mathrm{~m}$ deep in the talus matrix adjacent to the hay pile. All iButtons for the longitudinal study were programmed to record temperatures at 4-h intervals, starting at noon (12:00) on the day of deployment, with instrument accuracy set to $\pm 0.5{ }^{\circ} \mathrm{C}$. Data were downloaded and iButtons reprogrammed and reinstalled annually.

For the intensive behavioral study at the South Coulee site, thermochrons were installed on 3 July 2013 and removed on 31 August 2013. Instrument accuracy was within $\pm 0.5{ }^{\circ} \mathrm{C}$, and the thermochrons recorded temperatures at 1-h intervals beginning at 18:00 on the day of deployment. Four vertical transects perpendicular to the talus-forefield border and separated by approximately $50 \mathrm{~m}$ were established. A single thermochron was placed at the talus-forefield edge of each transect, and matched pairs were secured at approximately $10 \mathrm{~m}, 20 \mathrm{~m}$, and $30 \mathrm{~m}$ upslope from the talus edge following the design of Millar et al. (2014). We deployed the paired iButton packages such that one package was secured in a shaded locality near the talus surface and one inserted as close as possible to $1 \mathrm{~m}$ deep into the talus matrix. Ambient air temperatures were recorded at 2 positions at the same elevation as the study site but $40 \mathrm{~m}$ south of the talus, with instrument placements $2 \mathrm{~m}$ high in Jeffrey pines on the north side of the trunk in a shaded position.

We refer to the talus positions with pairs of thermochrons (surface and matrix) as "slope stations." Therefore we had 2 stations in the forest, 4 stations in the talus forefield, and 12 matched pairs of talus slope stations. Data 
from the 2 forest thermochrons were highly correlated and thus averaged; similarly the 4 thermochrons from the forefield were correlated and averaged. Data from the paired iButtons at each slope station were further analyzed by subtracting the matrix recordings from the surface temperatures to yield a time series of temperature differences. Given the nature of the data, we expected and observed both diurnal and seasonal deterministic variation in each time series. Diurnal variation was removed by subtracting each measure from the mean value of all measures taken in that hour. For example, the mean for all data taken at 12:00 was subtracted from each data point at 12:00, and so on. Seasonal deterministic variation in the resulting residuals was removed by linear regression. The result in every case was a clearly nonstationary time series, where both mean and variance appear to be sensitive to idiosyncratic weather events. Computations and analyses were performed using $\mathrm{R}$ version 3.1.2.

\section{Vegetation Sampling}

Vegetation cover and composition at the South Coulee talus forefield were quantified on 13 July 2013 with standard point-quarter (quadrant) sampling (Brower and Zar 1977). Transect lines were established running perpendicular to the talus edge into the forefield centered on our best estimate of the horizontal center of each pika's territory. Pointquarter samples were taken at 4 distances from the talus edge: $1 \mathrm{~m}, 5 \mathrm{~m}, 10 \mathrm{~m}$, and $15 \mathrm{~m}$. For some territories, not all distances could be measured when the transect line crossed dirt access roads within $15 \mathrm{~m}$ of the talus edge. Plant species diversity, vegetation density, and vegetation coverage were assessed in each quadrant. We computed total density (TD; number of plants per square meter) and percent total coverage $(\mathrm{C}$; a metric that incorporates the size of individual plants; Brower and Zar 1977). It was not possible to establish a complementary transect running up the talus face due to instability of the slope (Loney 1968); we present photographic evidence of the sparse spacing of plants used by pikas when they forage on the talus slope (Fig. 1, Supplementary Material 1).

\section{Pika Populations}

The presence of pikas in the Mono Craters was first observed by A.T. Smith on 23 Sep- tember 1969, and the population at the South Coulee site was discovered in the early 1990s (A.T. Smith unpublished data). Beginning in 2009, we have documented pika occupancy at the South Coulee site annually (minimum of 2-4 person hours per year; Millar et al. 2013a; Table 1).

In 2012 (20-23 May) and 2013 (3 July), we intensively surveyed the pika population at the study site prior to initiation of behavioral studies. Additionally, we surveyed the population at the site between 12 July and 17 July 2014 and 22 July 2015 to document population persistence over the winters of 2013-2014 and 2014-2015, respectively. These surveys, conducted by multiple observers stationed at intervals facing the broad reach of our study site and who communicated whereabouts of observed pikas, were designed to estimate the number of adult pikas holding territories on the talus face. We did not capture and mark individuals (the only way to obtain an absolute count of pikas in a population and to determine fine-scale behavioral interactions among individuals; sensu Tapper 1973, Smith and Ivins 1983a, 1984), as our objective was to determine rates of behaviors within the population. Subsequent detailed behavioral observations of our population supported our initial survey number (see below).

To determine how representative our South Coulee study population is within the region, we also surveyed other nearby potential sites for pika occupancy in the Mono and Inyo Craters that could have served as steppingstones for pika colonization of the Mono Craters (Table 1). In the Inyo Craters, the Obsidian Dome and Little Glass Flow sites have been evaluated annually since 2009, and the nearby Glass Flow site since 2013 (2-4 person hours per year; Millar et al. 2013a, 2016). Additionally, in 2012, five person hours were spent conducting detailed observations at Obsidian Dome. At Wilson Butte we spent 17 person hours in 2012 and 9 person hours in 2013 searching for pika sign and presence in what appeared to be suitable pika habitat. We monitored talus areas in the northern reach of the Mono Craters at the Northwest Coulee and North Coulee sites since 2011 and 2013 , respectively (2 person hours per site per year; Millar et al. 2013a). These sites are $5 \mathrm{~km}$ and $8 \mathrm{~km}$ distant, respectively, from the behavioral study site and situated at lower 
elevations. We also surveyed active habitat areas adjacent to (east and west of) the South Coulee study site in 2012 (19 person hours), 2013 (11 person hours), and 2014 (7.5 person hours).

\section{Behavioral Sampling}

Behavioral data were gathered using timed scan sampling of unmarked focal individual pikas (Altmann 1974), and the method closely approximated the protocol of Smith and Ivins (1984) in their study on Colorado pikas. Observers were positioned on a berm rising across from the forefield and in front of the home range of 1 of the 9 pikas on the site (Fig. 1). The wide spacing of individuals and the large home ranges that each animal occupied minimized the chances of double counting a behavior. Position on the talus and unique pelage patterns facilitated identification of focal animals during an observation period. In $291.25 \mathrm{~h}$ of observation $(22.75 \mathrm{~h}$ in 2012 and $268.5 \mathrm{~h}$ in 2013), we are unaware of any instances where the behavior or movement trajectory of one of the pikas in the study population was altered due to the presence of an observer. Observers gathered data on a focal animal in 15-min time periods, normally extending over 2- to 3-h blocks; observation blocks were randomized throughout the day, and hours of observation extended from 06:00 to 20:00. Additionally, the study area was observed for 7 observation periods between 22:00 and 23:00 and 12 observation periods between 23:00 and 24:00 to determine activity and vocalization rates at night. Behavioral data were collected from 20 May to 23 May 2012, and from 4 July to 14 July and 30 August to 1 September 2013.

Sampling units in the behavioral study were the 15-min observation periods. When summarizing the data, however, we binned sampling units by hour, where the sixth hour was from 06:00 to 06:59, the seventh from 07:00 to 07:59, and so forth. Each observation period was assigned to the hour in which most of its duration fell. For example, a 15-min observation period starting at 07:50 would be classified as occurring in the seventh hour. Behavior rates were calculated by summing the total number of times a given behavior was observed in a given hour, dividing by the number of sampling units in that hour, and then multiplying by 4 to give our estimate of mean number of times the focal animal engaged in a behavior in a given hour of the day. Per-hour standard deviations, and therefore standard errors (SE), were calculated similarly; standard deviation among sampling units was converted from "per 15 minutes" to "per hour."

Behavioral data included vocalizations, nonsocial behaviors, and social behaviors following the definitions in Smith and Ivins (1984). Notes were taken on the presence of predators, unusual ambient conditions, or any other factor that may have influenced the behavior of a focal animal. Vocalizations included short calls (most often the double-note bleat characteristic of Sierra Nevada pikas, sometimes a single or triple note), alarm calls (repetitive short calls), and long calls or songs (generally characterized by a string of bleats lasting up to $30 \mathrm{~s}$ beginning with single notes, then double notes, and punctuated with a triple note). Long calls are uttered only by males (Severaid 1955, Krear 1965, West 1981, Smith and Ivins 1984). All vocalizations were tallied.

Nonsocial and social behaviors were recorded during each minute; because we used continuous sampling, the recording of one behavior within a minute did not preclude the recording of another. Nonsocial behaviors included cheek rubs (a sideward motion to deposit secretions from an apocrine gland, used to demarcate territory; Meaney 1987), haying (carrying vegetation in the mouth to deposit into a hay pile for subsequent utilization, primarily to serve as a source of food during the winter; Millar and Zwickel 1972b, Conner 1983a, Smith and Ivins 1984), feeding (direct consumption of vegetation; Huntly et al. 1986), locomotion (running across a surface), and surveillance (sitting quietly, generally on a backward-facing large rock; "musing" of Kawamichi 1976). In 2013 we also coded whether activities occurred on the talus or in the forefield. If the activity occurred in the forefield, we estimated the distance from the talus edge to where the behavior occurred.

Social behaviors included conspecific aggression (a pika chasing another pika), social tolerance ( 2 pikas sitting within $3 \mathrm{~m}$ of each other and cognizant of one another, without an ensuing chase), conspecific avoidance (one pika altering its trajectory to avoid another pika, without an ensuing chase), and predator avoidance (movement away from 
the threat of an approaching predator; Smith and Ivins 1984).

\section{REsults}

\section{Temperature Profile}

South Coulee Study Site.-Temperature time series from each slope station exhibited reproducible patterns consistent with an insulating effect of the talus (Figs. 2, 3). Every time series is qualitatively similar; diurnal temperature variations are less marked in the talus matrix compared to the surface (Fig. 2). In almost every case (the East Low station being the only exception), relative to the matrix temperatures, surface temperatures were warmer during the day and cooler at night throughout the study (Fig. 2, Supplementary Material 3). In the single exception, surface temperatures were warmer than matrix temperatures during the day, but no difference was evident at night. On average, matrix temperatures were $8{ }^{\circ} \mathrm{C}$ cooler than on the surface at the hottest part of the day and about $2{ }^{\circ} \mathrm{C}$ warmer at the coldest point of the early morning (Supplementary Material 3). The West High station exhibited the highest daily extremes (Fig. 2) and also the greatest differences between surface and matrix temperatures during the day (Fig. 2, Supplementary Material 3). In general, temperature profiles in the forefield mirrored those on the slope surface, especially the lower stations (Figs. 2, 4A). However, the forefield and the slope surface tended to experience warmer daily highs than measured in the adjacent forest (Figs. 2, 4B).

The detailed temperature time series for midsummer 2013 compare favorably in overall trends to data from our 5-year monitoring of talus temperatures at the South Coulee site (Fig. 5). However, talus matrix temperatures in the longitudinal study (thermochron situated on a shallow rocky berm separated from the main talus) did not exhibit the extreme cool and buffered pattern of the matrix temperatures on the main talus slope. All years had more than 45 days with temperatures $>28^{\circ} \mathrm{C}$, and 2010 had 67 days that exceeded that threshold (Fig. 5; Millar et al. 2016). Our behavioral sampling occurred near the hottest period of the summer (Fig. 5, shaded region), and the apparent insulating effect of talus, as measured by the difference between surface and matrix temperatures, tended to be most pronounced on the hottest days (Fig. 6). In other words, the talus matrix provided the best thermal refugia on those days in which pikas would be most stressed while active on the surface (e.g., days when the high temperature on the talus surface approached and sometimes exceeded $40{ }^{\circ} \mathrm{C}$ ).

To orient these results in the context of a longer timescale, we examined the detailed daily and seasonal temperature records, as obtained from the Western Regional Climate Center (http://www.wrcc.dri.edu), from the closest and most representative site: Mammoth Lakes Ranger Station (MLRS), 37.6478 - $118.9617^{\circ}$, elevation $2379 \mathrm{~m}, 20 \mathrm{~km}$ south of the South Coulee study area. This record extends 22 years from 1994 to 2015 and appears to be nearly equivalent to the climate at the South Coulee study area. The average daily high temperature over the same range of days (4-31 July 2013) was $25.36{ }^{\circ} \mathrm{C}$ at the MLRS and $25.38{ }^{\circ} \mathrm{C}$ from the tree placement thermochrons at the South Coulee site, and the highest temperatures recorded were $32.2{ }^{\circ} \mathrm{C}$ and $31.0{ }^{\circ} \mathrm{C}$ at the 2 sites, respectively. Over the 22-year record at the MLRS site, the average monthly high temperature was highest in July (range $28-33^{\circ} \mathrm{C}$ ), and the 6 highest recorded temperatures were all in July $\left(33^{\circ} \mathrm{C}\right.$ twice; $32{ }^{\circ} \mathrm{C}$ on 4 occasions-one of these occurring in 2013). At the South Coulee site the 3 hottest days in July 2013 were 30.0, 30.5 , and $31{ }^{\circ} \mathrm{C}$, and the warmest day that occurred during the time of our behavioral measurements was $29^{\circ} \mathrm{C}$.

Obsidian Dome, Inyo Craters.-Our 5year temperature series at the hay pile (surface) and matrix positions at Obsidian Dome showed similar interannual and seasonal trends to those at South Coulee (Supplementary Material 4). In general, summer temperature extremes were lower than at South Coulee, but hay pile temperatures exceeded $30{ }^{\circ} \mathrm{C}$ during the summers of 2010, 2013, and 2014. Matrix temperatures

Fig. 2 (see page 467). Temperature time series for surface and matrix (talus) thermochrons at each data station at South Coulee from 3 July to 31 August 2013. Stations were oriented in 4 lines running up the talus slope (West, West/Middle, East/Middle, and East), with 4 stations on each line (Forefield, Low, Middle, and High). Low, Middle, and High stations all had 2 thermochrons each: a (shaded) surface instrument (black lines) and a deep matrix instrument (red lines). 

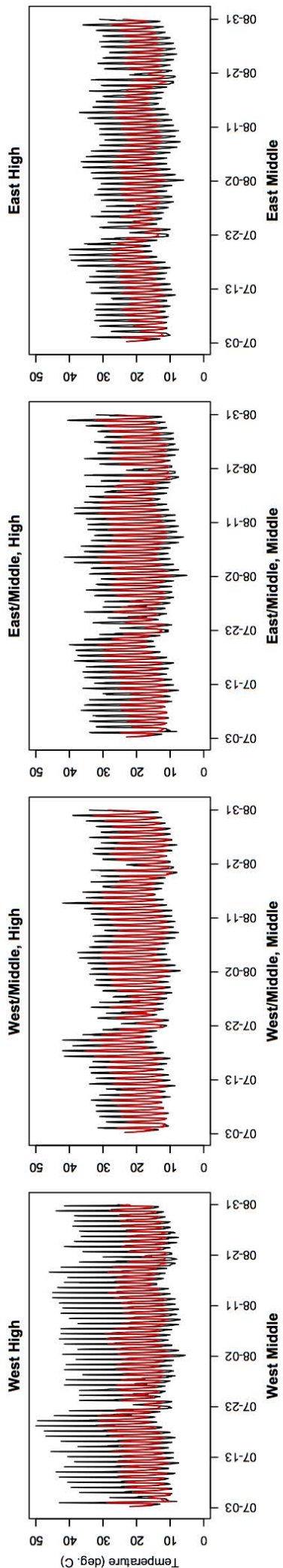
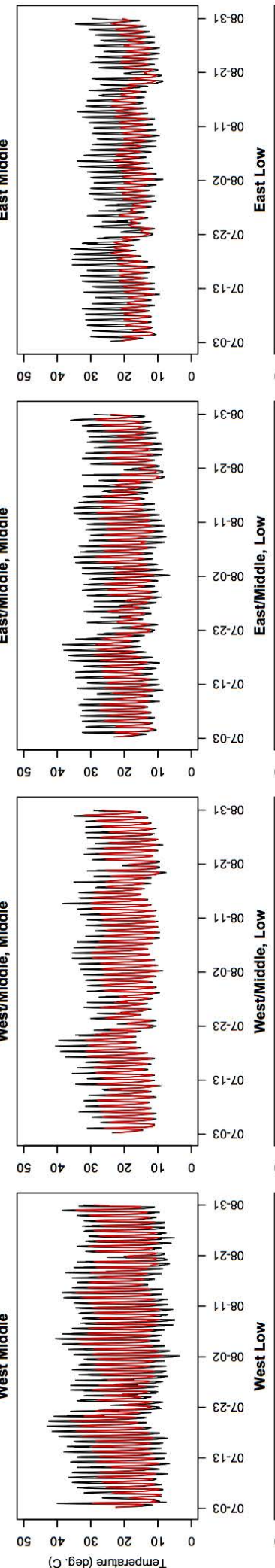
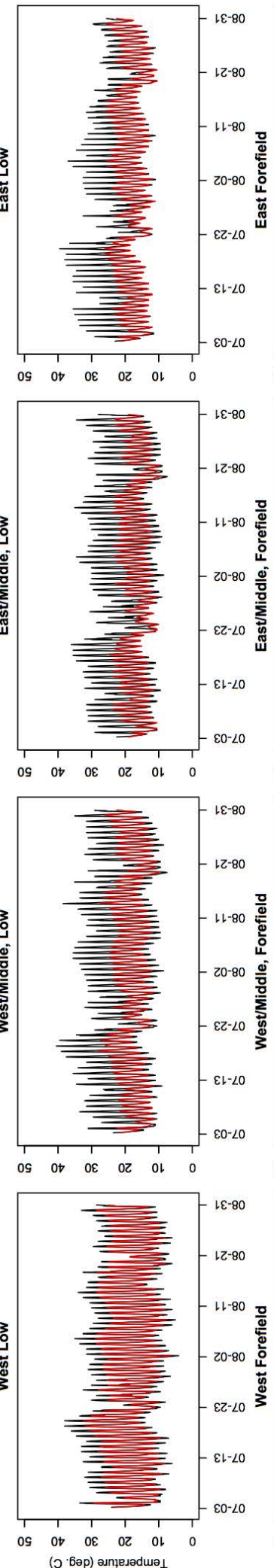

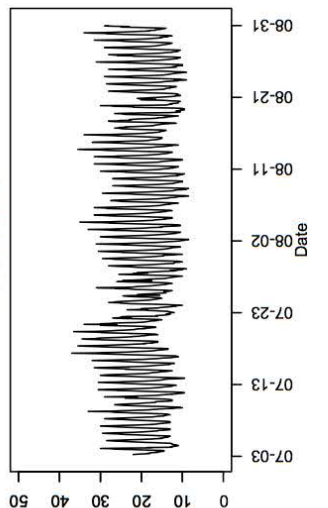

os $\quad$ ot $\quad$ of $\quad 0 z$ ol $\quad 0$
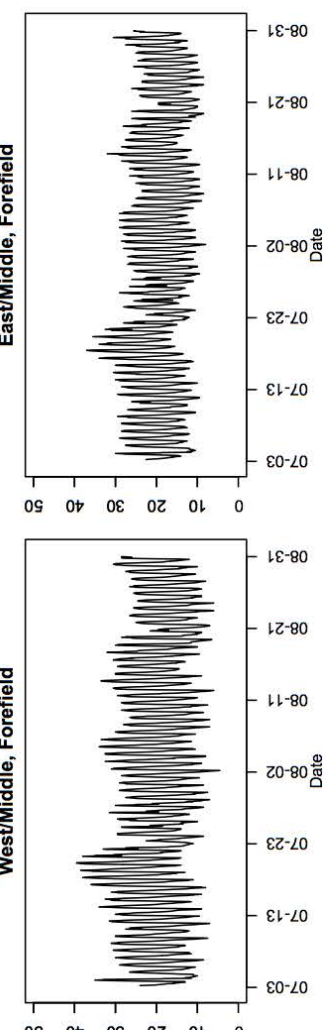

$\begin{array}{llllll}0 S & 0 t & 0 \varepsilon & 0 Z & \text { ol } & 0\end{array}$

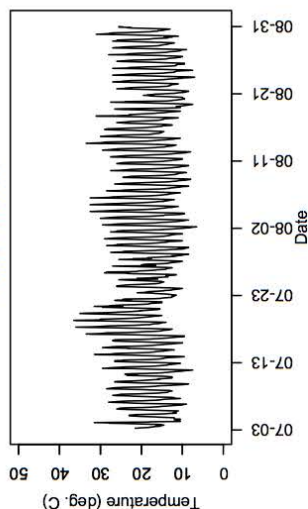



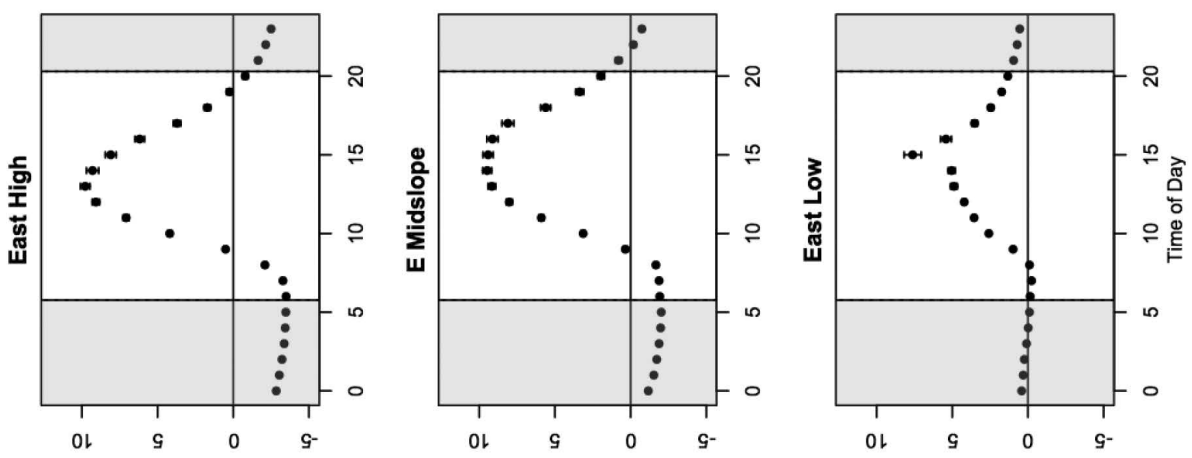

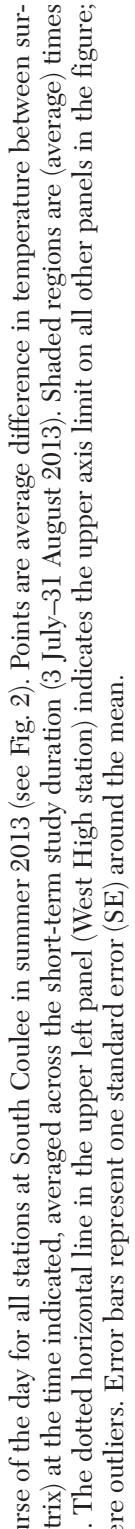
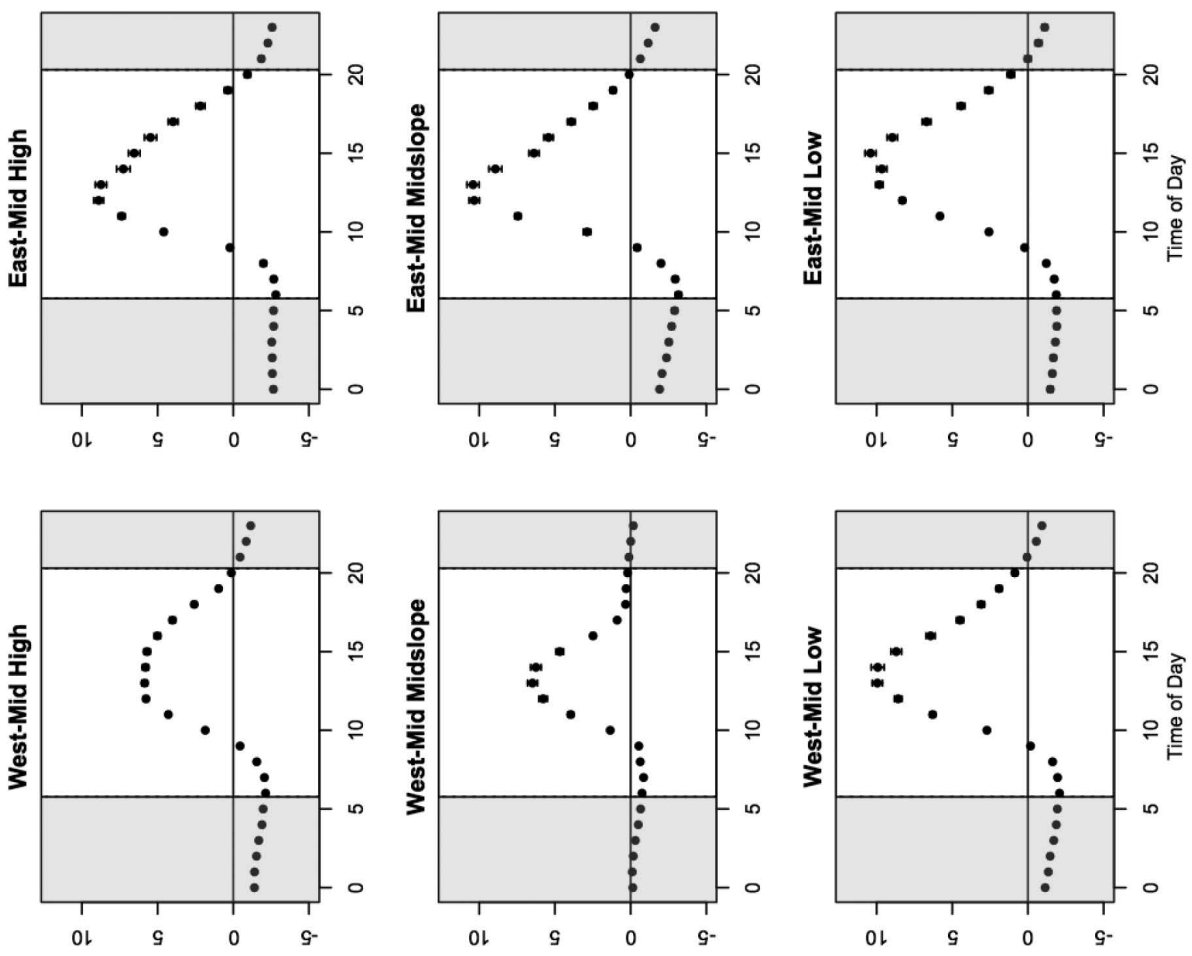

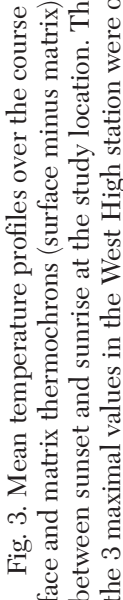
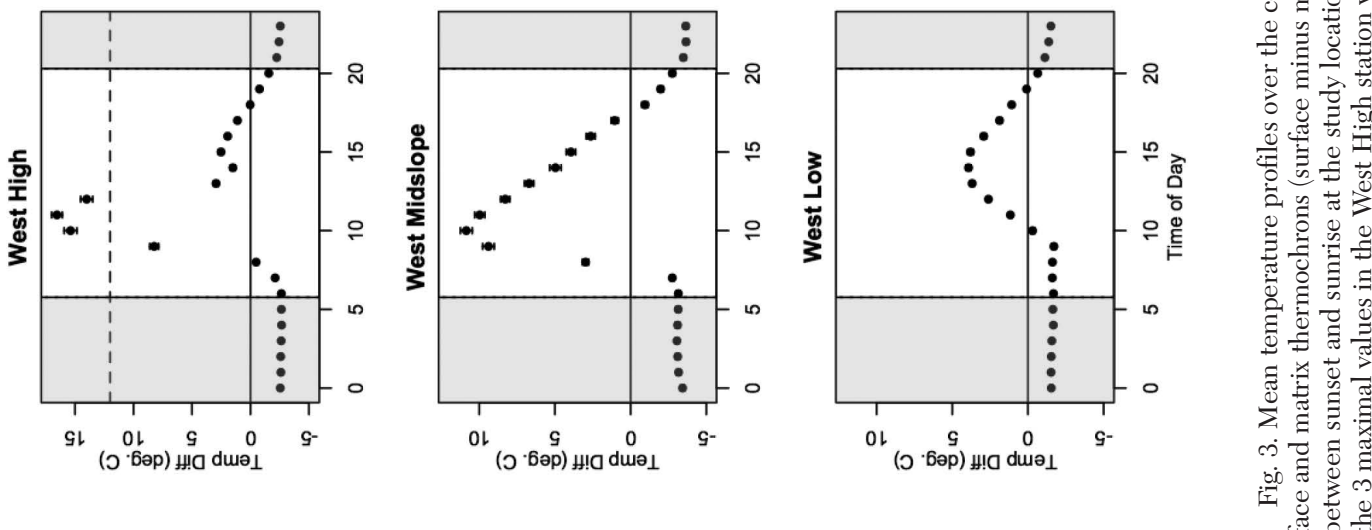

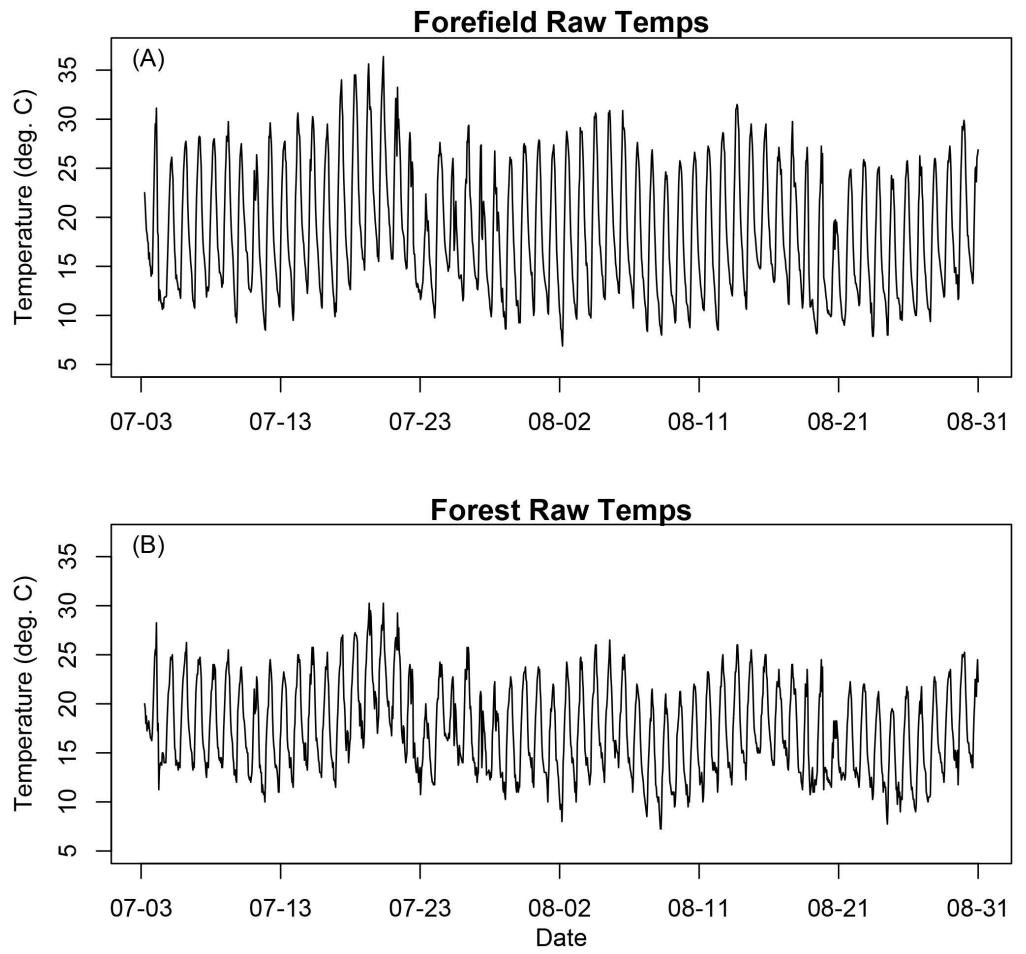

Fig. 4. Time series of temperatures measured at South Coulee in (A) the forefield thermochrons (see Fig. 2) and (B) the forest adjacent to the study slope. The forefield values are averaged across 4 instruments, and the forest time series is averaged across 2 instruments.

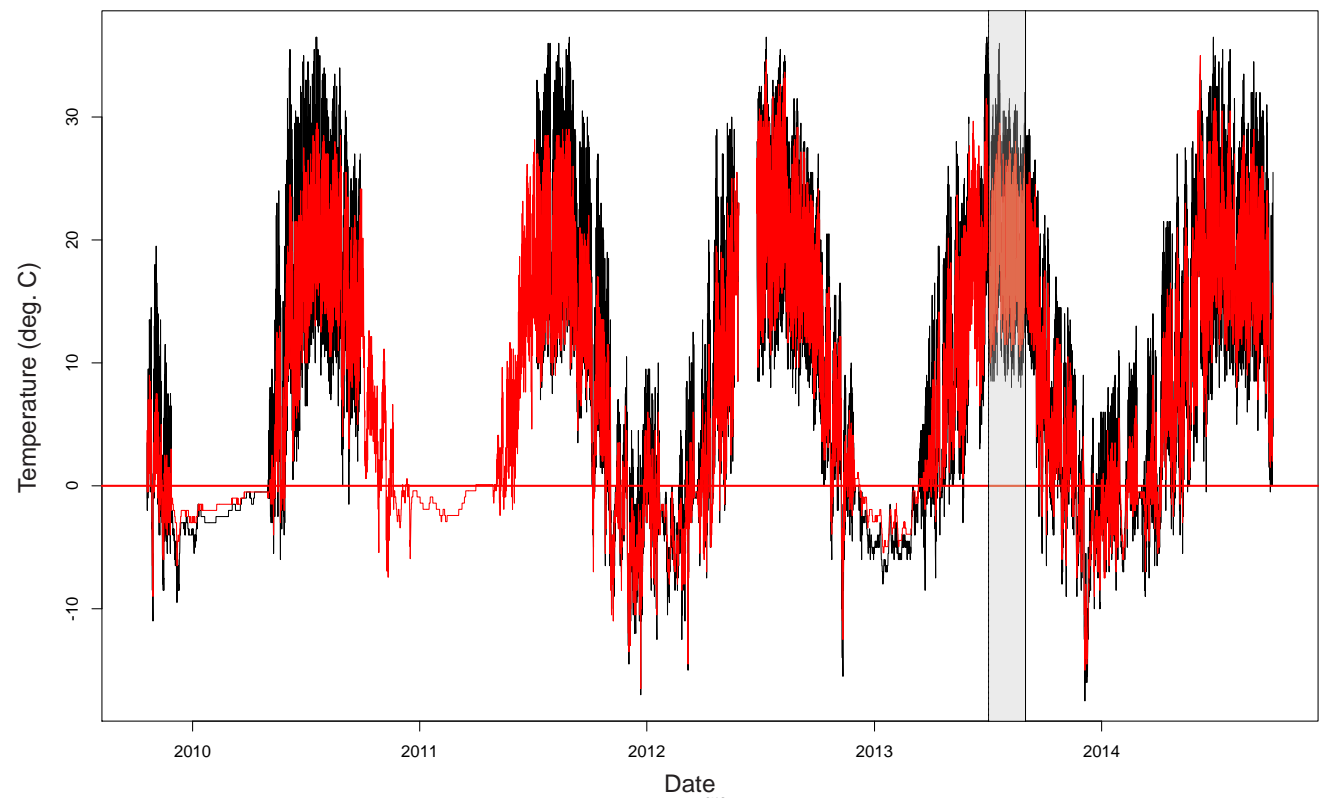

Fig. 5. Multiyear (2009-2014) temperature profile time series at the Mono Craters. Black lines represent hay pile (surface) temperatures; red lines represent matrix temperatures. The shaded area in 2013 represents the time of behavioral sampling. 


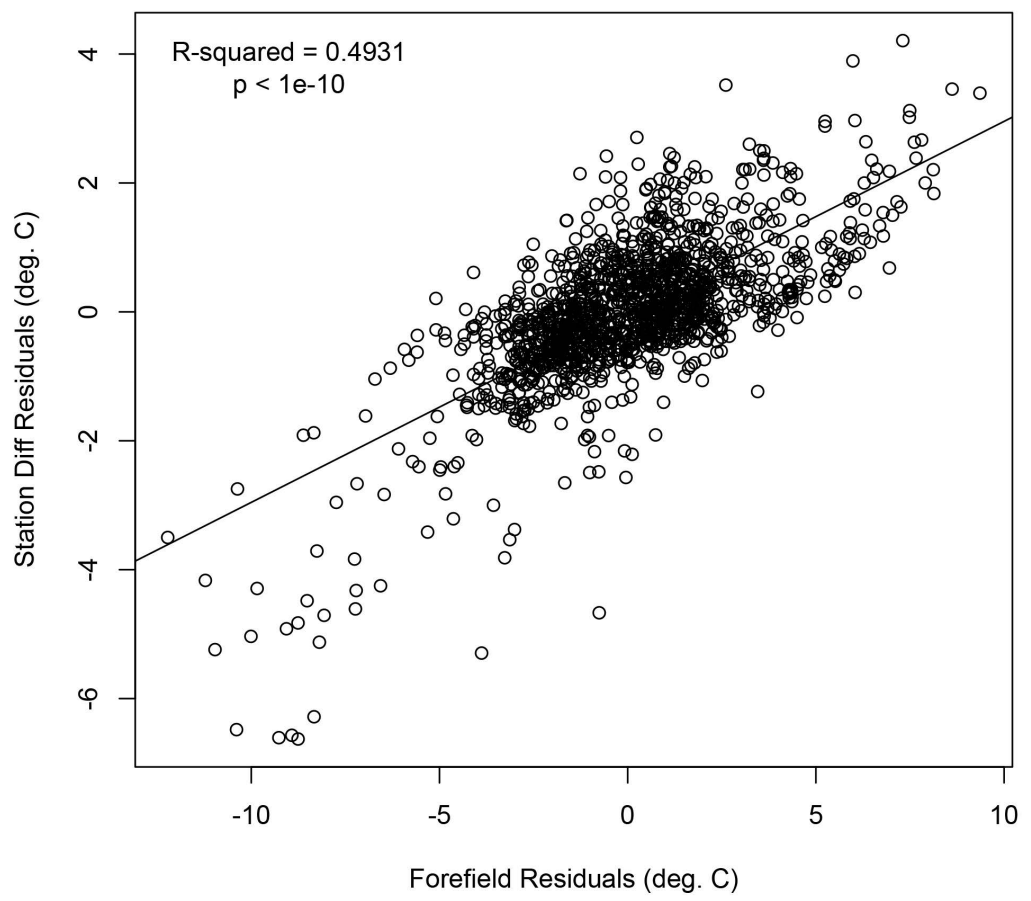

Fig. 6. Correlation plot of station difference residual temperatures (mean difference at each time across stations minus mean difference at all stations across the entire South Coulee study) versus residuals in forefield temperatures (mean temperature of the 4 forefield thermochrons at each time minus mean temperatures of both instruments across the entire study).

TABLE 2. Total vegetation density (TD) and percent vegetation coverage $(\mathrm{C})$ across the forefield of the Mono Craters talus. Numbers of quadrats at the 4 distances are unequal due to site topography (see text).

\begin{tabular}{lccc}
\hline $\begin{array}{l}\text { Distance } \\
\text { from talus } \\
\text { edge }(\mathrm{m})\end{array}$ & $\begin{array}{c}\text { Number } \\
\text { of quadrats }\end{array}$ & $\begin{array}{c}\text { Total } \\
\text { density }\end{array}$ & $\begin{array}{c}\text { Vegetation } \\
\text { coverage } \\
(\%)\end{array}$ \\
\hline 1 & 8 & 0.31 & 8 \\
5 & 7 & 0.34 & 5 \\
10 & 6 & 0.77 & 13 \\
15 & 4 & 0.94 & 32 \\
\hline
\end{tabular}

below hay piles showed the more common summer pattern for pika talus (Millar et al. 2016), whereby average matrix temperatures were much lower than at the surface, and variances were greatly dampened. In winter at the Obsidian Dome talus, snow cover buffered temperatures at the hay pile site for 3 of the winters, but not substantially or at all during the winters of 2011-2012 and 2013-2014.

\section{Vegetation Availability}

Plant species at the South Coulee site are uncharacteristic of those found normally at higher-elevation sites more typically occupied by American pikas. The study area vegetation primarily included the shrubs Purshia tridentata, Ericameria nauseosa, Linanthus pungens, Holodiscus discolor, and Ribes spp.; herbaceous perennials Angelica lineariloba, Eriogonum umbellatum, Castilleja chromosa, Galium multiflorum, Cryptantha confertiflora, and Phlox spp.; annuals Phacelia cremulata and Gayophytum spp.; and graminoids Carex rossii, Elymus elymoides, and Stipa occidentalis.

Compared to the mesic environments that produce abundant forage for pikas living adjacent to montane meadows (Huntly et al. 1986), the environment faced by the pikas at the South Coulee site is extremely sparse, more heavily shrub dominated, and xeric adapted. Total density of individual plants per square meter (TD) was $<1$ at all distances from the talus edge (Table 2). As half of the point-quarter measurements at $1 \mathrm{~m}$ from the talus edge extended back into the talus, TD was lowest at this distance; however, the extremely low value for TD demonstrates the lack of vegetation close to the talus-forefield 
interface. TD increased with distance from the talus edge, such that pikas often had to forage long distances from the safety of the talus habitat (see Behavioral Observations section). Percent coverage (C) was also very low across the entire reach of the study area forefield. Average $\mathrm{C}$ was highest at a distance of $15 \mathrm{~m}$ from the talus edge and was very low at distances closest to the talus (Table 2; see also Fig. 1 and Supplementary Material 1).

The general composition of the forefield vegetation can be indexed by the sample size of plant types and their average diameters from all 25 point-quarter measurements (therefore 100 samples): 34 grasses, diameter $=0.45 \mathrm{~cm} ; 11$ annuals, diameter $=4.7 \mathrm{~cm}$; 20 herbaceous perennials, diameter $=31.5 \mathrm{~cm}$; and 35 shrubs, diameter $=61.1 \mathrm{~cm}$.

Occasional widely spaced shrubs-predominantly E. nauseosa, H. discolor, and Ribes spp.- - and the herbaceous perennial A. lineariloba punctuated the steep talus slope (Fig. 1, Supplementary Material 1). Pikas heavily utilized this source of food (see Behavioral Observations section), and these plants composed nearly the entire diet of some of the study area pikas because the forefield was either barren or shortened due to dirt access roads that ran close to 3 of the territories at the eastern end of the study area.

\section{Pika Populations}

The South Coulee pika population has been extant during every survey since we began monitoring in the early 1990s. In both years during which detailed behavioral measurements were taken (2012 and 2013), the study area population comprised 9 pikas spaced horizontally east to west along a talus-edge extension of approximately $300 \mathrm{~m}$. Thus the linear extent of forefield per pika averaged approximately $35 \mathrm{~m}$. The 3 easternmost pika territories (pikas \#1, \#2, and \#3) had limited natural forefield as a dirt road leading east to an active pumice mine cut very close to the talus edge. Similarly, an abandoned spur side road running east to west cut through the middle of the territory occupied by pika \#9 at the far west of the study area. Pikas \#2 and \#3 occasionally ran across the mine access road, and pika \#9 was commonly seen running both across and along the center of the spur road. The forefield for pikas \#4 through
\#8 extended across a depression separating the talus edge from the spur road (Fig. 1). In 2014 and 2015 we verified the persistence of pikas (or their replacements) on 8 of the 9 territories; we could not confirm the presence of pika \#9 (a pika that may or may not have been the resident pika was observed to the west of this territory).

In our less-intensive longitudinal surveys of talus habitat in the Mono Craters, we have observed pikas and/or evidence of residence (fresh hay piles/scats) at the NW Coulee site since 2011, except in 2012 when we did not visit the site. At the very low-elevation North Coulee site, we observed pikas and one green hay pile only in 2013 (Table 1). During the span of years encompassed by this study, there were active populations extending both $\mathrm{NE}$ and $\mathrm{W}$ of the study area (following the curvature of the South Coulee to the right and left of our study area). It is likely that additional pika populations occur in the Mono Craters.

Wilson Butte is the closest site adjacent to the southern Mono Craters (linear distance to the South Coulee study area is approximately $6 \mathrm{~km}$ ) with a large rock talus formation that could have served as mainland pika habitat and as a stepping-stone for the colonization of pikas to the Mono Craters. We spent significant effort trying to locate active or inactive sign of pikas at this locality without success (Table 1).

Farther south in the Inyo Craters $(8-10 \mathrm{~km}$ from the behavioral study site and $1.5-3 \mathrm{~km}$ south of Wilson Butte), we have observed occupancy at the main talus on Obsidian Dome since 2009, with the exception of 2011, and occupancy for the 3 years of observation at Glass Flow Dome. At Little Glass Flow, we observed occupancy in 2009, 2010, 2012 , 2013 , and only old sign in 2011,2014 , and 2015 (Table 1).

\section{Behavioral Observations}

Overall activity.- The South Coulee pikas were infrequently active; focal animals were observed in only $26.4 \%(307 / 1165)$ of all 15-min observation periods and in only $10.3 \%(1801 / 17,475)$ of all minutes of observation. The most commonly observed activities engaged in by pikas at the South Coulee site were locomotion and surveillance. The rarest behaviors were cheek rubbing-an 


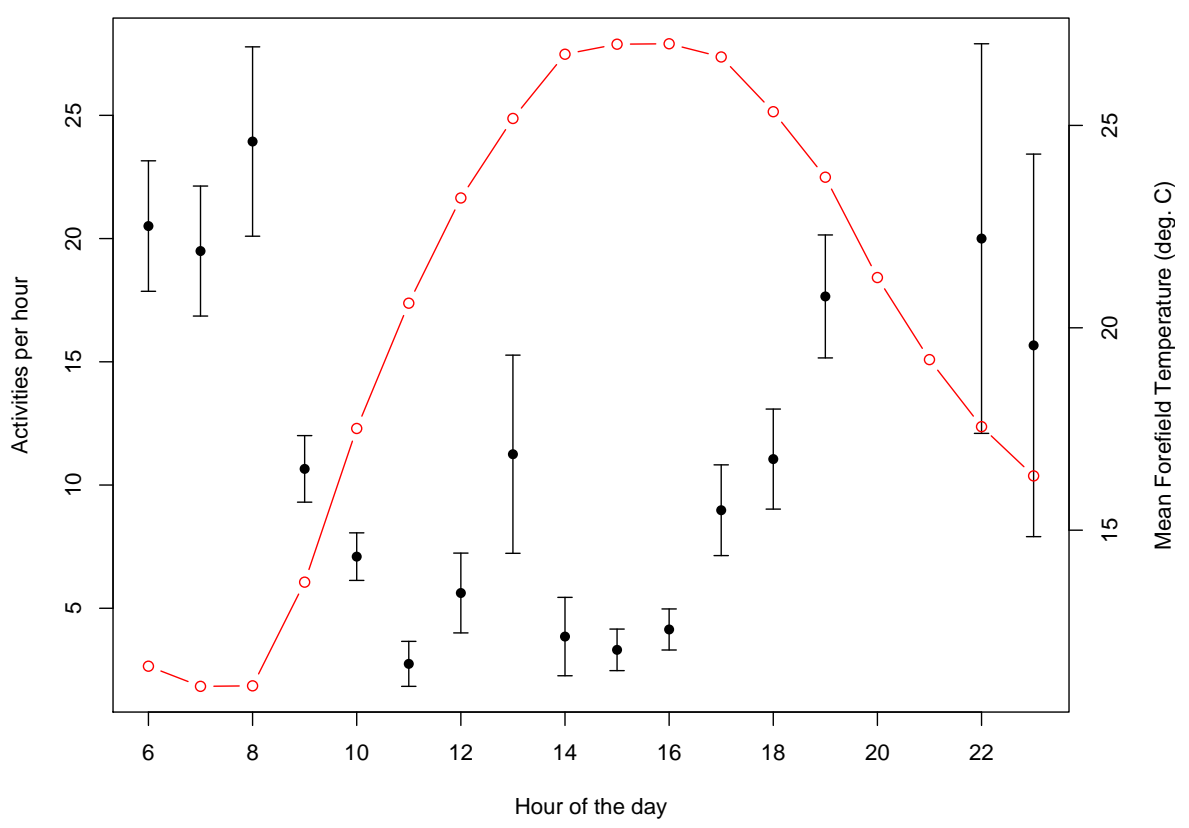

Fig. 7. Rates of activity engaged in by American pikas (Ochotona princeps) at the South Coulee site during the summers of 2012 and 2013 by time of day (black) and compared with mean forefield temperature (red). Error bars represent one standard error $(\mathrm{SE})$ around the mean.

TABLE 3. Rates of behaviors displayed by American pikas (Ochotona princeps) at Mono Craters, California. Values for behavior frequency and occurrences per hour are based on observations during $291.25 \mathrm{~h}$ of focal animal observation in 2012 and 2013.

\begin{tabular}{llrc}
\hline \multirow{2}{*}{ Behavior } & Type & Frequency & $\begin{array}{c}\text { Occurrences } \\
\text { per hour }\end{array}$ \\
\hline Vocalization & Short call & 1141 & 3.92 \\
& Alarm call & 35 & 0.12 \\
\multirow{4}{*}{ Nonsocial } & Long call & 26 & 0.09 \\
& Cheek rub & 6 & 0.02 \\
& Locomotion & 806 & 2.77 \\
& Surveillance & 644 & 2.21 \\
& Haying & 119 & 0.41 \\
Social & Feeding & 213 & 0.73 \\
& Aggression & 3 & 0.01 \\
& Social & 4 & 0.01 \\
Interspecific & tolerance & & \\
& Avoidance & 0 & 0.00 \\
& Predator & 6 & 0.02 \\
\hline \multirow{5}{*}{ avoidance } & & \\
\hline
\end{tabular}

activity only observed 6 times-and social interactions (Table 3).

TIMING OF ACTIVITY.-Activity by pikas was concentrated in the early morning and late-afternoon hours when temperatures were cooler than those during midday (Figs. 7, 8). Notably, however, activity did not completely cease during midday; thus, pikas did not entirely avoid warm temperatures. Pika activity, both sightings and vocalizations, also occurred during our nocturnal observation sessions (although these data are marked by wide confidence intervals due to small sample size; Figs. 7, 8).

ForaGiNG.-Foraging occurred at an overall rate of 1.14 times per hour, with most foraging involving direct feeding bouts $(0.73 / \mathrm{h})$ versus haying activity $(0.41 / \mathrm{h}$; Table 3$)$. In 2013 we recorded the occurrence of foraging on the talus $(\mathrm{OT})$ versus on the forefield $(\mathrm{FF})$. Where possible, we estimated the distance an activity occurred in the FF from the talus-FF edge. Pikas were observed feeding OT $74 \%$ of the time, whereas only $26 \%$ of direct feeding observations occurred on the FF $(N=161)$. Forefield feeding occurred on average $20.3 \mathrm{~m}$ from the talus-FF edge $(N=31)$.

Haying trips, both FF and OT, were observed 103 times, $50 \%$ of which were by a single pika, \#8. This individual hayed in the FF 47 times. No other pikas in the study population were seen accumulating hay from the FF. Forty of the 52 haying observations of pika \#8 occurred in a single 1.5 -h period between 


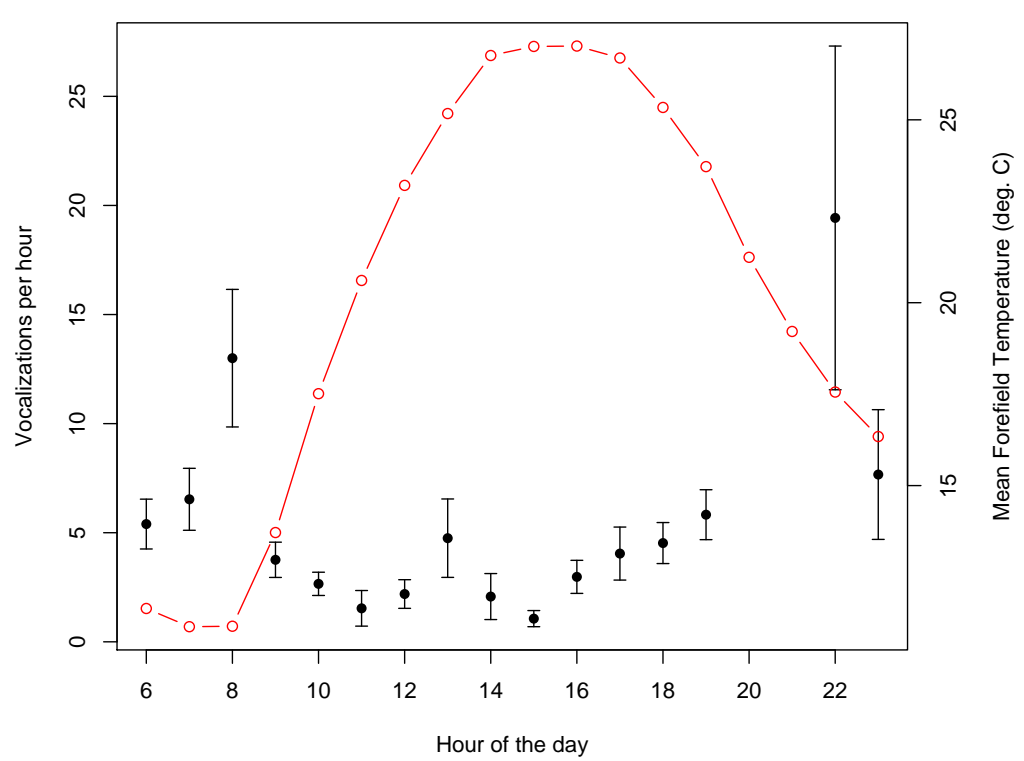

Fig. 8. Rates of vocalizations uttered by American pikas (Ochotona princeps) at the South Coulee site during the summers of 2012 and 2013 by time of day (black) and compared with mean forefield temperature (red). Error bars represent one standard error (SE) around the mean.

06:00 and 08:00; thus, this one haying bout encompassed $39 \%$ of all haying activity observed in 2013. Pika \#8 was commonly observed running across exposed rhyolite sand interspersed with occasional pumice or obsidian boulders (but presenting no true refuge sites) to clumps of vegetation 27-33 m from the talus edge to gather hay. Five observations of haying by pika \#8 and all haying observations of 6 other pikas occurred OT. Two pikas were never observed to engage in any haying activity and one was observed haying only once. If the haying activity of pika \#8 is discounted, the rate of haying by all other pikas (including 6 observations in 2013 without a FF or OT designation) was $0.21 / \mathrm{h}$.

None of the pikas we observed had recognizable central-place haypiles such as are characteristic of most American pika populations. Instead, it appeared that the South Coulee pikas were scatter-hoarding vegetation, as hay placement was distributed widely across the field of activity of each pika that engaged in haying activity. However, wellformed hay piles had been seen earlier at the site, both where the hay pile iButton was positioned in 2009 (this hay pile was actively constructed in some years and not in others) and in the general area occupied by pika \#8 (as observed in 2011). Thus the behavior of constructing hay piles at the South Coulee site has been variable among years.

VOCALIZATIONS.-Pikas vocalized audibly in $35.5 \%(413 / 1165)$ of the 15 -min observation periods. Short calls were heard most frequently and were given by all pikas in the study population; long calls, a vocalization uttered only by males, were uttered far less frequently (Table 3). Alarm calls (rapidly repeated short calls), usually given in response to a terrestrial predator (normally a longtailed weasel) or an avian predator, were heard 35 times. Weasels were seen frequently as they had numerous chipmunks and squirrels as potential prey in addition to pikas at the study site. Occasionally alarm calls were given in response to large nonpredatory birds that soared over the study area. Overall rate of vocalizations heard per hour was 4.13 , and like overall activity, vocalizations were most commonly heard during the cooler early morning and late-afternoon observation sessions, as well as at night (Fig. 8).

Social BeHavior.-Rates of social behaviors were extremely low; in almost $300 \mathrm{~h}$ of observation, intraspecific aggression was noted only 3 times and social tolerance 4 times (Table 3). There were no recorded instances 
of conspecific avoidance, and predators were avoided on 6 occasions.

\section{Discussion}

\section{General Activity}

We present the first systematic and comprehensive observations of pika behavior and activity in a low-elevation warm interior marginal location. These results present a stark contrast with the natural history of pikas in populations located at range centers (generally cool, high-elevation sites) where conditions are thought to be optimal. A generalized behavioral profile of the American pika has been established largely by studies of individually marked animals living in upper montane settings (Krear 1965, Sharp 1973, Tapper 1973, Svendsen 1979, Smith and Ivins 1983a, 1984), and these investigations have been largely corroborated by numerous other studies on high-elevation pikas in which individuals were not marked. Few of these investigations give clear rate-specific data on individual behaviors, and some concentrate only on one or a few key behaviors. Our observation protocol followed most closely that of Smith and Ivins (1983a, 1984, 1986, 1987) and Ivins and Smith (1983), the Colorado study that most comprehensively portrays the activity and behavioral profile of American pikas in an upper montane setting based on $1581 \mathrm{~h}$ of minute-by-minute focal animal sampling. We also present comparative unpublished data from focal animal observations of pikas at a nearby low-elevation site (Bodie; $2619 \mathrm{~m} ; 40 \mathrm{~km}$ north) and a high-elevation Sierra Nevada site (Lost Lake; 3361 m) 19 km west from the South Coulee study site (Supplementary Material 5).

Pikas in upper montane and alpine settings appear to be far more active than pikas at the South Coulee site. In Colorado, pikas were surface active over 30\% (Smith and Ivins 1986) and $61 \%$ (Conner 1983a) of the time, and Montana pikas were surface active $41 \%$ of the time (Barash 1973). Otto et al. (2015) found pikas active 27\% (Colorado) and 29\% (Wyoming) of the time. Pikas in the nearby Sierra Nevada were surface active $36 \%$ of the time (Supplementary Material 5). In contrast, the South Coulee pikas were seen during only $10.3 \%$ of all observation minutes. In addition, we failed to see focal pikas during
$73.6 \%$ of our 15-min observation sessions, and no pika vocalizations were heard during $64.5 \%$ of sessions.

South Coulee pikas were also active and vocalized at night (Figs. 7, 8), as has been documented in certain other locations (Krear 1965, Smith 1974a, and informal accounts by several investigators). At Bodie, the frequency of nocturnal calling sometimes surpassed the rate of calling during the day (Smith 1974a). Pikas there were even observed foraging and active throughout their territory at night (Smith 1974a), paralleling our observations at the South Coulee site. Similarly, some Asian pikas (O. pusilla, O. pallasi) may exhibit nocturnal activity (Sokolov et al. 2009). On the other hand, Massing (2012) attempted to document nocturnal behavior in Sierra Nevada pikas but was unsuccessful. Nocturnal activity could possibly extend the time available to engage in meaningful behaviors and therefore may represent a facultative response of American pikas living at low elevations. A dedicated study on this aspect of pika activity is clearly needed.

The most common activities of pikas are surveillance and locomotion. South Coulee pikas engaged in both of these activities at significantly lower rates than have been documented in other studies (Table 4). The low total activity profile for pikas at the South Coulee site is due to the infrequency of observations of these common activities.

\section{Vocal and Olfactory Communication}

Overall rate of vocalizations by the South Coulee pikas was qualitatively similar to those from other studies of pikas (Tables 3, 4). There are no published rate data on frequency of alarm calls, although a detailed analysis of pikas in the Rocky Mountains highlighted that alarm calls are rare (Ivins and Smith 1983). Most alarm calling occurred in response to long-tailed weasels, and the low rate of observed predator avoidance behavior (Table 3) accentuates the infrequency of encounters with predators at the South Coulee site. Thus rates of alarm vocalizations appear largely determined by the occurrence of predators, coupled with the activity level of resident pikas allowing detection of this threat.

Frequency of long calls is highest early in the breeding season at any locality, with a brief peak in autumn (Krear 1965, West 1981, 
TABLE 4. Comparative rates of behaviors displayed by American pikas (Ochotona princeps) during summer. SM = Supplementary Material [online only].

\begin{tabular}{|c|c|c|c|c|}
\hline Behavior & Type & $\begin{array}{l}\text { Occurrences } \\
\text { per hour }\end{array}$ & Region & Source \\
\hline \multirow[t]{13}{*}{ Vocalization } & Short call & 3.92 & Mono Craters & This study (Table 3) \\
\hline & Short call & 1.83 & Bodie, CA & Smith (unpublished; SM 5) \\
\hline & Short call & 3.80 & Sierra Nevada, CA & West (1981) \\
\hline & Short call & 2.44 & Sierra Nevada, CA & Smith (unpublished; SM 5) \\
\hline & Short call & 2.88 & Rocky Mts., CO & Smith and Ivins (1984) \\
\hline & Short call & 6.60 & Rocky Mts., CO & Conner (1983b) \\
\hline & Short call & 15.00 & Rocky Mts., CO & Svendsen (1979) \\
\hline & Short call & 6.72 & Rocky Mts., Alberta & Sharp (1973) \\
\hline & Long call & 0.09 & Mono Craters & This study (Table 3) \\
\hline & Long call & 0.21 & Bodie, CA & Smith (unpublished; SM 5) \\
\hline & Long call & 1.30 & Sierra Nevada, CA & West (1981) \\
\hline & Long call & 0.70 & Sierra Nevada, CA & Smith (unpublished; SM 5) \\
\hline & Long call & 0.08 & Rocky Mts., CO & Smith and Ivins (1984) \\
\hline \multirow[t]{5}{*}{ Surveillance } & & 2.21 & Mono Craters & This study (Table 3 ) \\
\hline & & 5.34 & Bodie, CA & Smith (unpublished; SM 5) \\
\hline & & 8.22 & Sierra Nevada, CA & Smith (unpublished; SM 5) \\
\hline & & 11.31 & Rocky Mts., CO & Smith and Ivins (1984) \\
\hline & & 13.80 & Rocky Mts., CO & Conner $(1983 a)$ \\
\hline \multirow{3}{*}{ Locomotion } & & 2.77 & Mono Craters & This study (Table 3) \\
\hline & & 3.58 & Bodie, CA & Smith (unpublished; SM 5) \\
\hline & & 5.30 & Sierra Nevada, CA & Smith (unpublished; SM 5) \\
\hline \multirow{5}{*}{ Cheek-rubbing } & & 0.02 & Mono Craters & This study (Table 3 ) \\
\hline & & 5.80 & Rocky Mts., CO & Meaney (1987) \\
\hline & & 4.70 & Rocky Mts., CO & Svendsen (1979) \\
\hline & & 0.27 & Rocky Mts., CO & Conner (1983b) \\
\hline & & 0.28 & Rocky Mts., CO & Smith and Ivins (1984) \\
\hline \multirow[t]{12}{*}{ Foraging } & Feeding & 0.73 & Mono Craters & This study (Table 3 ) \\
\hline & Feeding & 1.31 & Bodie, CA & Smith (unpublished; SM 5) \\
\hline & Feeding & 1.64 & Sierra Nevada, CA & Smith (unpublished; SM 5) \\
\hline & Feeding & $\begin{array}{l}1.07 \\
4.69\end{array}$ & Rocky Mts., CO & Smith and Ivins (1984) \\
\hline & Feeding & 3.80 & Rocky Mts., CO & Conner (1983a) \\
\hline & Feeding & 8.50 & Glacier NP, MT & Barash (1973) \\
\hline & Haying & 0.41 & Mono Craters & This study (Table 3) \\
\hline & Haying & 3.22 & Bodie, CA & Smith (unpublished; SM 5) \\
\hline & Haying & 6.34 & Sierra Nevada, CA & Smith (unpublished; SM 5) \\
\hline & Haying & 2.57 & Rocky Mts., CO & Smith and Ivins (1984) \\
\hline & Haying & 13.83 & Rocky Mts., CO & Conner $(1983 a)$ \\
\hline & Haying & 18.70 & Glacier NP, MT & Barash (1973) \\
\hline \multirow[t]{6}{*}{ Social } & Aggression & 0.01 & Mono Craters & This study (Table 3) \\
\hline & Aggression & 0.17 & Rocky Mts., CO & Smith and Ivins (1984) \\
\hline & Tolerance & 0.01 & Mono Craters & This study (Table 3 ) \\
\hline & Tolerance & 0.19 & Rocky Mts., CO & Smith and Ivins (1984) \\
\hline & Avoidance & 0.00 & Mono Craters & This study (Table 3) \\
\hline & Avoidance & 0.05 & Rocky Mts., CO & Smith and Ivins (1984) \\
\hline
\end{tabular}

Smith and Ivins 1984). For example, in the Rocky Mountains, $67 \%$ of long calls were made in May (Smith and Ivins 1984). Long calls were heard infrequently at the South Coulee site, most likely because our observations were taken past the active breeding season. Nevertheless, the frequency of long calls at the South Coulee site appeared to be significantly lower than observed in the nearby Sierra Nevada and Bodie sites (Table 4 ), where data were also collected late in the summer and past the breeding season.
Short calls function to advertise territory and to deter intrusions by conspecifics. In fact, conspecifics are more likely to intrude onto a resident pika's territory when the resident is inactive, this status being noted by the absence of calling (Smith and Ivins 1986). Frequency of short calls at South Coulee fell within the range reported in several high montane studies; only the rate of short calling at Bodie (low elevation) was lower than that at South Coulee (Table 4). Conner (1983b) found that the frequency of short calls was highly 
correlated with level of surface activity (which was high at this site; Table 4). Thus it is interesting that despite their depressed overall activity, the South Coulee pikas produced short calls at a rate similar to pikas in other settings. Apparently short call rate is fixed as being necessary to ensure the integrity of a pika's territory.

Scent marking by cheek-rubbing apparently serves as a mechanism to mark and advertise a pika's territory (Meaney 1987). This behavior was essentially absent at the South Coulee site, being seen only 6 times (rate of $0.02 / \mathrm{h}$; Table 3). Even the lowest of these rates in comparative studies is an order of magnitude greater than that observed at the South Coulee site (Table 4). Apparently South Coulee pikas roam so widely over the talus that there was limited opportunity to scent mark efficiently. In montane populations we have observed pikas frequenting the same rocks for observation points and using identical pathways through the talus over time. In this context, scent marking may convey more accurately the domain (territory) of a pika than is possible in the setting at the South Coulee site.

\section{Foraging Dynamics}

One of the largest behavioral discrepancies between the South Coulee pikas and those in other comparative studies was in foraging activity (Table 4). South Coulee pikas were observed feeding only 0.73 times/h and haying 0.41 times/h (Table 3; 0.21 times/h if the activity of pika \#8 is discounted). In contrast, Conner (1983a) found that haying activity in August in Colorado occupied 55\% of the time pikas were surface active.

Haying is one of the characteristic behaviors of pikas, and their hay piles are also a centerpiece of their natural history. In earlier years, before we began our behavioral work, we had located 2 characteristic pika hay piles at the South Coulee site. Neither was active during the time of our investigation; the territory immediately to the west of our study site had become active again during summer 2015. Most observations consisted of pikas scatter hoarding vegetation across the area of their respective territories rather than constructing a central-place hay pile. These small stores were difficult to locate; in only a few instances could the caches be seen from the surface.
The foraging pattern of the South Coulee pikas varied from that of typical upper montane pikas (Huntly et al. 1986). Only one pika exhibited the characteristic repetitive backand-forth haying between forefield and talus, and even this pika traveled on average much farther from the talus edge to collect hay $(27-33 \mathrm{~m})$ than did pikas in the Colorado Rockies $(\bar{x}=7.5 \mathrm{~m}$; Huntly et al. 1986). Feeding by pikas at the South Coulee site was also more likely to occur on the talus than in the forefield. Because of the sparse availability of plants in the forefield (Table 2), the average observed distance traveled from the talus border to feed (over $20 \mathrm{~m}$ from the talus edge) was far greater than the typical feeding distance found in upper montane pikas $(2.2 \mathrm{~m}$; Huntly et al. 1986). The reticence of the South Coulee pikas to venture onto the forefield to forage is likely related to their aversion to exposure to predators. The low rate at which foraging was observed overall likely results from the ability of the South Coulee pikas to continue foraging on talus shrubs throughout the winter.

Why were the characteristic behaviors of haying and accumulating large central-place hay piles not a dominant aspect of the repertoire of pikas at the South Coulee site? First, the sparse availability of plants in the forefield and the long distance of most plants from the talus edge (Table 2) decreased the benefit of haying versus the cost of this behavior due to exposure of pikas to predators. A second possibility for the lack of large hay piles is the low snow accumulation characteristic of the steep south-facing slope on the South Coulee. Even following significant storms, snow melts off the upper slopes relatively rapidly, thus exposing talus shrub vegetation. Pikas living in snow-free locations forage year-round and do not build hay piles (American pikas-Ray and Beever 2007, Simpson 2009, Varner and Dearing 2014a, Shinderman 2015, Varner et al. 2016; Ochotona macrotis-Kawamichi 1968, 1971; Ochotona roylei-Kawamichi 1968, Bhattacharyya et al. 2013). Third, American pikas deprived of vegetation in the forefield due to excessive grazing by domestic livestock may facultatively concentrate on haying plants that grow within the talus (Millar 2011), a behavior also exhibited by the South Coulee pikas.

The high variability of haying behavior of American pikas calls into question the adaptive significance of this behavior (see Millar 
and Zwickel 1972b, Conner 1983a, Ivins 1984, Dearing 1997). Several studies have found that an increase in the amount of available vegetation leads to an increase in pika density (Millar 1971, Wilkening et al. 2011, Jeffress et al. 2013, Erb et al. 2014, Yandow et al. 2015, Varner et al. 2016), and several of these studies go further to say that pika populations in areas with a lower percentage of vegetative cover are at increased risk of extirpation (Wilkening et al. 2011, Jeffress et al. 2013, Erb et al. 2014). On the other hand, Shinderman (2015) determined that varying levels of vegetation cover were not associated with frequency of pika occurrence. The most comprehensive examination of the effect of vegetation quantity on pika fitness was conducted by Millar $(1971,1974)$ in Alberta. He examined 3 habitat types (sparse, stunted, lush) that varied in pika density from 4 to 22 animals/ha. Across this gradient, the quantity of available forage $\left(\mathrm{g} / \mathrm{m}^{2}\right)$, quality of available forage (percent protein), and average hay pile size decreased along the gradient from lush to stunted to sparse habitat available to pikas. In spite of these changing metrics, however, across this gradient there were no differences in (1) percent protein in hay piles at each site (indicating that selectivity increased as vegetative quality decreased; see also Smith and Erb 2013); (2) mean litter size from successful pregnancies in the following summer; and (3) physiological fitness of adults (as measured by a fat index; Millar 1971, 1974). Similarly, within sites the average size of hay piles made by juveniles was significantly smaller than those made by adults, yet in the following breeding season there was no difference in average litter size between these yearlings and adults age 2 or older (Millar 1971). Millar also conducted manipulations, removing surface hay piles from the territories of pikas on 3 sites and adding $1000 \mathrm{~g}$ of vegetation to hay piles of 75 marked animals in 4 discrete populations; an additional region with no manipulations served as a control. The following year he found no difference in survival and reproductive success among these areas (Millar 1971:50, Sharp 1973:48). Thus it appears that while declining availability of vegetation may reduce pika density, this effect does not necessarily jeopardize population fitness. Average horizontal distance across the territories of the South Coulee pikas was over $30 \mathrm{~m}$, the upper end of territory size in American pikas (Smith and Weston 1990), and these territories extended far up the talus slope; thus, this was a very low-density population. However, in spite of the lowered density and paltry availability of vegetative resources, the population documents the capacity of American pikas to persist in a marginal setting.

The quality of vegetation available to pikas may also influence their fitness. All investigations of the composition of forage accumulated in hay piles compared with the vegetation available to an individual pika have shown that pikas are highly selective, normally harvesting plants higher in protein, nitrogen, or water content (e.g., Krear 1965, Millar and Zwickel 1972b, West 1981, Smith and Erb 2013). Several studies claim that a predominance of forbs leads to higher fitness, and that a switch in vegetation from forbs to graminoids that may accompany global warming could cause extirpation of pika populations (Rodhouse et al. 2010, Erb et al. 2011, 2014, Wilkening et al. 2011, Yandow et al. 2015). On the other hand, in Alberta graminoids were the most abundant vegetation type in $36 \%$ of all hay piles, and they were 1 of the 3 most highly selected vegetation types (Millar and Zwickel 1972b). Similarly, graminoids are a common vegetation type in many environments occupied by pikas and represent a common element (in many situations, the only plant species) in their hay piles (Smith and Erb 2013; Smith, Nagy, and Millar personal observations). As highlighted above, reproductive performance and individual fitness were not correlated with any measure of quality of available vegetation or eventual hay pile size (Millar 1971).

The dominant vegetation at the South Coulee site was shrubs, followed by herbaceous perennials. The graminoids that were present were small, inconspicuous, and only available in the forefield, which was not heavily utilized by the South Coulee pikas. Many studies have documented American pikas in low, hot, dry sites harboring similar xeric-adapted vegetation (Angelica, Artemisia, Ericameria, Holodiscus, Linanthus, Purshia, Ribes; Severaid 1955, Smith 1974a, Rodhouse et al. 2010, Wilkening et al. 2011, Collins and Bauman 2012, Millar et al. 2013a, Shinderman 2015), and the foraging by South Coulee pikas also appears to represent use of this vegetation. 
Water content in vegetation appears to be an important variable with respect to foraging decisions made by pikas; pikas in drier locations were more selective of plants with higher water content than pikas occupying more mesic sites (Smith and Erb 2013). Additionally, populations may be at increased risk of extirpation in areas of low annual precipitation (Erb et al. 2011), although Jeffress et al. (2013) determined that precipitation by itself was not a strong explanatory variable in determining pika persistence. Use of xeric-adapted forbs (as itemized above), perhaps coupled with increased selectivity, might allow pikas to persist in dry environments. The forefield at the South Coulee site comprises extremely porous rhyolite sand that has very little capacity for holding moisture; therefore the forefield vegetation at this site may provide the driest known habitat where pikas can occur. On the talus, however, the shrubs and herbaceous perennials may be able to tap into moisture provided by the subtending layer of permafrost (Supplementary Material 2A, 2B; Loney 1968); thus, this vegetation could adequately provide water necessary for pika persistence.

\section{Social Behavior}

Social interactions between pikas appear to be opportunistic and not premeditated. The broken talus habitat and wide spacing of the individually territorial pikas ensures that encounter rates are few. In Colorado, Smith and Ivins (1984) documented low rates of intraspecific aggression, social tolerance, and conspecific avoidance; at the South Coulee site, these rates were even lower by over an order of magnitude (Table 4). These low rates follow from the depressed level of overall activity; South Coulee pikas were rarely in a position to interact, even with neighbors. The extremely low rate of these behaviors (only 7 episodes noted) prevented us from further characterizing the social dynamics within this population.

\section{Thermal Environment and Timing of Activity}

American pikas tend to be more active during morning and evening hours, although in cooler high-elevation sites they may be consistently active throughout the day (Severaid 1955, Krear 1965, MacArthur and Wang 1974, Smith 1974a, Massing 2012, Otto et al. 2015). At Bodie, pikas were significantly less active as temperatures increased during summer, when midday temperatures commonly exceeded $20{ }^{\circ} \mathrm{C}$. In spring, when temperatures were cooler $\left(<10^{\circ} \mathrm{C}\right)$, pikas were active during all hours of the day (Smith 1974a). The activity behavior pattern of pikas at the South Coulee site paralleled those found at Bodie: the animals were most active between 06:00 and 08:00 and between 17:00 and 20:00, the coolest times of the day. A surprising result, however, was that we saw a moderate level of activity during the midday hours, up to an average exceeding 10 sightings/h in early afternoon when the average ambient temperature rose above $20{ }^{\circ} \mathrm{C}$ (Fig. 7).

How does this activity pattern match the thermal environment in which these pikas occur? The talus at the South Coulee site represents a very hot locality for pikas. Forest air temperatures (Fig. 4B) consistently peaked at $>20{ }^{\circ} \mathrm{C}$, and frequently exceeded $25{ }^{\circ} \mathrm{C}$. These measurements parallel longterm data interpolated for our site from the closest meteorological station (MLRS). Forefield ground temperatures (Fig. 4A) were consistently $>25{ }^{\circ} \mathrm{C}$, and reached temperatures as high as $35^{\circ} \mathrm{C}$. More extreme were the surface temperatures on the talus, an environment directly experienced by pikas. Surface temperatures approached $50{ }^{\circ} \mathrm{C}$ at some stations and consistently peaked at $>30{ }^{\circ} \mathrm{C}$ (Fig. 2), as also recorded in our on-site longitudinal data (Fig. 5). These results parallel intensive thermal studies of pika talus habitats at similarly low-elevation locations in the Inyo Craters, Sierra Nevada, and western Great Basin (Millar et al. 2014, 2016). Controlled experiments have demonstrated that pikas may die when they are confined-thus unable to behaviorally thermoregulate-and exposed to sustained temperatures as low as $25.5-29.4{ }^{\circ} \mathrm{C}$ (MacArthur and Wang 1973, Smith 1974a). These lethality-threshold temperatures are significantly lower than those to which the pikas are regularly exposed at the South Coulee site. What, then, might be enabling pikas to persist in what appears to be a thermally stressful environment?

Clearly the role of the talus matrix is critical for pika survival. Our 2 study site talus matrix temperatures were consistently far more moderate than were surface temperatures (Figs. 2, 3, 5 and Supplementary Material 3, 4 ), an effect that became more pronounced as 
surface temperatures increased (Fig. 6). While this pattern is consistent with prior results, at the South Coulee and Obsidian Dome sites the pattern was more extreme than at many other monitored locations (Millar et al. 2013b, 2014, 2016, Moyer-Horner et al. 2015, Otto et al. 2015). At our study sites, mean temperatures of the matrix were consistently and significantly cooler than surface temperatures, a finding not always the case for upper montane pika taluses in the adjacent Sierra Nevada (Millar et al. 2014). Further, although matrices previously have been observed to have attenuated diurnal variation relative to surface temperatures (MacArthur and Wang 1973, Beever et al. 2010, Wilkening et al. 2011, Henry et al. 2012), daily variances at our 2 volcanic sites were extremely low. This combined effect means that matrices remained cool and highly buffered from external air fluctuations and temperature extremes even on the hottest days and peak hours of warmth. Cool talus interiors at the South Coulee and Obsidian Dome sites, in turn, appear to provide reliable and easily accessible refuges for pikas, which could account for the midday surface activity we observed by pikas.

Cool and buffered matrix temperatures at pika-occupied sites have been attributed to the presence of subsurface ice in nonvolcanic taluses (Millar and Westfall 2008, 2010, Millar et al. 2014, 2016, Wilkening et al. 2015), as well as in lava flow pika habitats at low elevations, such as Lava Beds National Monument (Beever 2002). Although solid ice in lava caves is readily visible, subsurface ice in fractured rock features (such as rock glaciers and periglacial taluses) and in volcanic features (such as are present in the Mono and Inyo Craters) is not usually visible from the surface. Rather, diffuse interstitial ice, small to large ice lenses, and congelation ice in a matrix of rock and soil can extend pervasively throughout subsurfaces of these features (Harris and Pederson 1998, Haeberli 2005, Juliussen and Humlum 2008). Presence of ice has been attributed to percolation of water from melting snow and precipitation that subsequently freezes at depth, often forming permafrost. While ice might be assumed to be the source of cooling air in talus and lava flow matrices, in many natural rocky landforms, the opposite appears to be the case: unique internal circulation patterns related to the structure, depth, and porosity of coarse rocky layers, and involving convection, conduction, "chimney-flow" circulation, Balch circulation, and/or other as yet poorly understood processes, maintain subsurface freezing temperatures that in themselves lead to the development of ice (Millar et al. 2014 and references therein). The existence of one or more of these thermal processes in the Mono Craters and at Obsidian Dome is documented not only by the thermal profiles of the matrices we report, but by direct observation of ice during drilling and mining operations (Loney 1968:428).

In contrast to natural taluses that have internal circulation processes that cool matrices and lead to the development of subsurface ice, anthropogenic ore dumps at the low, warm Bodie site do not have such geomorphic structure and complexity, and they do not develop buffered thermal regimes as do natural landforms (C.I. Millar unpublished data). While talus matrix temperatures at Bodie remain cooler than external air, they nonetheless track external heat, and pikas must behaviorally thermoregulate by limiting activities to the coolest times of hot days (Smith 1974a). While not all naturally occurring taluses or volcanic features have the geomorphic attributes or thermal processes that promote unique and cold internal air circulation patterns, those that have these attributes enable pikas to persist in locations and elevations where regional climates and talus surface temperatures otherwise appear limiting. Whether in volcanic landforms or nonvolcanic montane taluses, the situation at Mono Craters and Obsidian Dome does not appear to be unique. Where these landforms are distributed, unusual internal thermal conditions develop such as we have observed. These can support pika occupancy over a much wider range of regional climatic conditions than has been assumed based on physiological capacity of the animals alone.

\section{Conclusions}

Many contemporary survey techniques designed to locate pikas rely on reconnaissance of short duration. For example, the protocol for determining pika occupancy in the National Park Service "Pikas in Peril" project calls for 2 min of quiet observation following approach to a site, followed by 15-35 min of searching for sign within a 12-m-radius search 
area (during which pikas could be easily disturbed and thus be unlikely to exhibit surface activity; Jeffress et al. 2011, see also Rodhouse et al. 2010). Should this or a similar protocol be employed to determine occupancy of the South Coulee site, it is highly likely that no animals would be encountered because of their low activity rate. Additionally, these rapiddetection techniques would also be unlikely to locate the scattered caches of the South Coulee pikas. The pikas at this site also fail to deposit the characteristic scat cones and massive accumulations of scats that are common in other areas occupied by pikas. Thus, the South Coulee site could easily be classified as unoccupied if rapid surveys relied on the documentation of active pika sign. With the increasing importance of surveying and studying populations near the range margins of species as we monitor for the effects of climate change, it is necessary to consider the flexibility and resilience that these populations may exhibit to ensure that they are properly accounted for.

Our work highlights the current unique suite of behaviors that allows pikas to persist in the hot, arid environment found at the South Coulee site. Additionally, our regional surveys have detected pikas in most talus habitats we have investigated throughout the Mono and nearby Inyo Craters, although Wilson Butte, situated between these ranges and containing ideal pika talus, appears to be currently unoccupied. It is unlikely that either of these ranges is positioned to receive immigrant pikas from the nearby Sierra Nevada; the distance separating these ranges is too great and the known dispersal distance of pikas is too short for this likelihood. Thus any contemporary extirpation of a population in these ranges is likely to be permanent, unless the site could be recolonized from a nearby population within either range. The long-term temperature data from the MLRS and our thermochrons set in talus at the Mono and Inyo Crater sites indicate that these pikas have long been faced with high temperatures that could lead to population extirpations-yet they persist. Thus these data help set a benchmark for interpreting the resilience of American pikas, especially as the intermontane west becomes increasingly affected by climate change.

Many contemporary papers highlight high temperature, altered vegetative components, and a lack of snow in winter as potential factors driving extirpation of American pika populations (e.g., Smith et al. 2004, Beever et al. 2010, 2011, Erb et al. 2011, 2014, Wilkening et al. 2011, Ray et al. 2012, Jeffress et al. 2013, Stewart et al. 2015, Yandow et al. 2015). How do the Mono Craters pikas inform this discussion?

High Temperature.-American pikas in the Mono Craters exhibit patterns of behavior unlike any other studied population of the species. Nearly all observed behaviors occurred at rates less than at other sites, particularly compared with populations found at higher, cooler elevations. The pikas at the relatively low-elevation, south-facing South Coulee site faced talus surface temperatures far exceeding most other previously studied populations of pikas. Thus it was not surprising that pikas were primarily active in early morning and late afternoon hours, as this pattern had been documented in other low-elevation pika populations. There was also a relatively high level of nocturnal activity. That a modest amount of activity was observed during midday hours was unexpected. The ability of the South Coulee pikas to persist in this environment was apparently due to their ability to retreat to very cool interstices in the talus, and this also allowed for the midday activity level. The need to frequently cool down in this environment during the summer by retreating into the talus was likely responsible for the depressed overall level of observed activity compared to upper montane populations of pikas. Thus, while the American pika is a temperature-sensitive species (MacArthur and Wang 1973, 1974, Smith 1974a, Otto et al. 2015), behavioral responses of pikas to high temperatures are complex, and their distribution cannot be defined solely by measures of ambient temperature.

FORAGING.-The greatly reduced frequency of foraging behaviors-both haying and feeding-could partially have resulted from the thermal environment that the South Coulee pikas occupied. The very sparse nature of vegetation in the forefield, however, probably was a major contributor to this finding. The presence of shrubs on the talus slope, and the availability of these shrubs during most of the winter, may have reduced the need for pikas to cache large hay piles during summer. A winter study to see if pikas actively forage from talus shrubs is needed. These results highlight that 
pikas are generalist herbivores-always making the best of any vegetative situation (Smith and Weston 1990)—and indicate that shifts in vegetation due to climate change are unlikely to lead to population-level declines.

Winter SNOWPaCK.- It is also possible that conditions faced by pikas during winter could lead to population extirpation. Although the pika is a cold-adapted species, pikas could become stressed and experience higher levels of mortality in years of low snowpack when the lack of insulative protection provided by snow forces them to expend additional energy for thermoregulation (Smith 1978, Beever et al. 2010, Ray et al. 2012). Our thermochron records (Fig. 5) indicate that no snow covered the hay pile site for most of the winters of 2011-2012 and 2013-2014, when temperatures dropped to $-17^{\circ} \mathrm{C}$. Additionally, throughout the Sierra Nevada, the snow water equivalent on 1 April 2015 was 5\% of its historical average: there was effectively no snow cover during the coldest months of the winter (Belmecheri et al. 2015). Thus, our population surveys in 2014 and 2015 could have found significant declines or extirpation of populations. However, only one territory at the South Coulee site was vacant during those summers, and extant populations were present at most of the other sites in the Mono and Inyo Craters (Table 1), again attesting to the resilience of pikas in this environment even when faced with extreme environmental conditions. The persistence of these populations refutes the contention that a consistent snowpack providing insulative protection is necessary for overwinter survival of American pikas.

In summary, our study expands what is known about American pika behavioral ecology in an unusual habitat and informs our general understanding of mammalian species' resilience to climate change. Importantly, our attention to animal behavior, focus on specific thermal conditions encountered by animals, and selection of a marginal environment for study yielded results contrasting those derived through climate-envelope or speciesdistribution modeling (see also Varner and Dearing 2014b). Studies on species that rely on generalized climate variables, optimum habitat conditions, and conventionally accepted animal behaviors rather than taking speciesspecific variation into account can lead to erroneous conclusions regarding the vulnerability of species to climate change.

\section{SupPlementary Material}

Five online-only supplementary files accompany this article (scholarsarchive.byu.edu/ wnan/vol76/iss4/7).

Supplementary Material 1. Two images showing the sparse forefield vegetation and the presence of scattered shrubs on the talus at the Mono Craters study site.

Supplementary Material 2. A, lacuna through which a current of cool air emanated from below the surface of rhyolite sand at Mono Craters; B, a FLIR (forward-looking infrared) camera image taken at 11:40 on 31 August 2013 showing the high contrast in temperatures between the surface of rhyolite sand on the slope and the cool air emanating from the lacuna at Mono Craters.

Supplementary Material 3. Time series of temperature deviations between surface and matrix thermochrons for all stations in summer 2013.

Supplementary Material 4. Long-term (winter 2010 to fall 2014) temperature time series at Obsidian Dome.

Supplementary Material 5. Rates of behaviors displayed by American pikas (Ochotona princeps) at Lost Lake and Bodie, Mono County, California.

\section{ACKNOWLEDGMENTS}

We could not have executed this research without the dedicated support of our field assistants: Sky Arnett-Romero, Badingqiuying, Samantha Basso, Kellie Elliot, Deborah Groves, Russell Haughey, Kody Holmes, Sabrina Jones, Elizabeth Leon, Cora McHugh, Logan Monks, Andrew Nemecek, Naomi Pier, Tricia Scales, Brandon Siqueros, Chalet Taylor, and Easton White. Ron Dorn kindly lent us the FLIR (forward-looking infrared) camera. Curtis Manley provided background of the geology of the South Coulee of the Mono Craters, including bringing the existence of the permafrost layer to our attention. Robert Westfall contributed to pika surveys at our study site and nearby formations. Identification of vegetation at the study site was provided by Jan Nachlinger. We thank John Alcock, Rob Klinger, Harriet Smith, and Easton White for their conscientious reading of and comments on a prior version of this manuscript. David Pearson and Manuel Plenge kindly translated the English abstract into Spanish. 


\section{Literature Cited}

Altmann, J. 1974. Observational study of behavior: sampling methods. Behaviour 49:227-266.

Barash, D.P. 1973. Territorial and foraging behavior of pika (Ochotona princeps) in Montana. American Midland Naturalist 89:202-207.

Beever, E.A. 2002. Persistence of pikas in two lowelevation national monuments in the western United States. Park Science 21:23-29.

Beever, E.A., P.F. Brussard, and J. Berger. 2003. Patterns of apparent extirpation among isolated populations of pikas (Ochotona princeps) in the Great Basin. Journal of Mammalogy 84:37-54.

Beever, E.A., C. Ray, P.W. Mote, and J.L. Wilkening. 2010. Testing alternative models of climate-mediated extirpation. Ecological Applications 20:164-178.

Beever, E.A., C. Ray, J.L. Wilkening, P.F. Brussard, AND P.W. Mote. 2011. Contemporary climate change alters the pace and drivers of extinction. Global Change Biology 17:2054-2070.

BeEver, E.A., AND J.L. Wilkening. 2011. Playing by new rules: altered climates are affecting some pikas dramatically_and rapidly. Wildlife Professional, Fall 2011:38-41.

Beever, E.A., J.L. Wilkening, D.E. McIvor, S.S. Weber, AND P.F. Brussard. 2008. American pikas (Ochotona princeps) in northwestern Nevada: a newly discovered population at a low-elevation site. Western North American Naturalist 68:8-14.

Belmecheri, S., F. Babst, E.R. Wahl, D.W. Stahle, and V. Trouet. 2015. Multi-century evaluation of Sierra Nevada snowpack. Nature Climate Change 6:2-3. http://dx.doi.org/10.1038/nclimate2809

Bhattacharyya, S., B.S. Adhikari, and G.S. Rawat. 2013. Forage selection by Royle's pika (Ochotona roylei) in the western Himalaya, India. Zoology 116:300-306.

BRIDLE, J.R., AND T.H. Vines. 2007. Limits to evolution at range margins: when and why does adaptation fail? Trends in Ecology and Evolution 22:140-147.

Brower, J.E., AND J.H. ZAR. 1977. Field and laboratory methods for general ecology. Wm. C. Brown, Dubuque, IA.

Brown, J.H. 1971. On the relationship between abundance and distribution of species. American Naturalist 105:467-478.

Collins, G.H., and B.T. Bauman. 2012. Distribution of low-elevation American pika populations in the northern Great Basin. Journal of Fish and Wildlife Management 3:311-318.

Conner, D.A. 1983a. Seasonal changes in activity patterns and the adaptive value of haying in pikas (Ochotona princeps). Canadian Journal of Zoology 61:411-416.

Conner, D.A. 1983b. Acoustic communication in pikas (Ochotona princeps). Doctoral dissertation, University of Colorado, Boulder, $\mathrm{CO}$

DEaring, M.D. 1997. The function of haypiles of pikas (Ochotona princeps). Journal of Mammalogy 78: $1156-1163$.

Erb, L.P., C. Ray, and R. Guralnick. 2011. On the generality of a climate-mediated shift in the distribution of the American pika (Ochotona princeps). Ecology 92:1730-1735.

Erb, L.P., C. Ray, and R. Guralnick. 2014. Determinants of pika population density vs. occupancy in the southern Rocky Mountains. Ecological Applications 24:429-435.

Guralnick, R. 2007. Differential effects of past climate warming on mountain and flatland species distributions: a multispecies North American mammal assessment. Global Ecology and Biogeography 16:14-23.

HAEBERLI, W. 2005. Investigating glacier/permafrostrelations in high areas: historical background, selected examples, and research needs. In: C. Harris and J.B. Murton, editors, Cryospheric systems: glaciers and permafrost. Geological Society, London, Special Publications 242:29-37.

Harris, S.A., AND D.E. Pedersen. 1998. Thermal regimes beneath coarse blocky materials. Permafrost and Periglacial Processes 9:107-120.

Henry, P., A. Henry, and M.A. Russello. 2012. Variation in habitat characteristics of American pikas along an elevation gradient at their northern margin. Northwest Science 86:346-350.

Hill, M. 2006. Geology of the Sierra Nevada. 2nd edition. University of California Press, Berkeley, CA.

Huntly, N.J., A.T. Smith, and B.L. Ivins. 1986. Foraging behavior of the pika (Ochotona princeps) with comparisons of grazing versus haying. Journal of Mammalogy 67:139-148.

Ivins, B.L. 1984. Territoriality, haypile function, and antipredator behavior in the pika, Ochotona princeps. Doctoral dissertation, University of California, Berkeley, CA.

Ivins, B.L., AND A.T. Smith. 1983. Responses of pikas (Ochotona princeps: Lagomorpha) to naturally occurring terrestrial predators. Behavioral Ecology and Sociobiology 13:277-285.

Jefrress, M.R., J. Apel, L.K. Garrett, G. Holm, D. LaRson, N. Nordensten, and T.J. Rodhouse. 2011. Monitoring the American pika (Ochotona princeps) in the Pacific West Region-Crater Lake National Park, Craters of the Moon National Monument and Preserve, Lassen Volcanic National Park, and Lava Beds National Monument: Narrative Version 1.0. Natural Resource Report. NPS/UCBN/NRR-2011/336. National Park Service, Fort Collins, CO.

Jeffress, M.R., T.J. Rodhouse, C. Ray, S. WolfF, and C.W. Epps. 2013. The idiosyncrasies of place: geographic variation in the climate-distribution relationships of the American pika. Ecological Applications 23:864-878.

Juliussen, H., AND O. Humlum. 2008. Thermal regime of openwork block fields on the mountains Elgahogna and Solen, central-eastern Norway. Permafrost and Periglacial Processes 19:1-18.

KaWAMICHI, T. 1968. Winter behavior of the Himalayan pika, Ochotona roylei. Journal of the Faculty of Science, Hokkaido University. Series VI, Zoology 16: $582-594$.

KaWAMichi, T. 1971. Daily activities and social pattern of two Himalayan pikas, Ochotona macrotis and $O$. roylei. Observed at Mt. Everest. Journal of the Faculty of Science, Hokkaido University. Series VI, Zoology 17:587-609.

KAWAMICHI, T. 1976. Hay territory and dominance rank of pikas (Ochotona princeps). Journal of Mammalogy $57: 133-148$

Krear, H.R. 1965. An ecological and ethological study of the pika (Ochotona princeps saxatilis Bangs) in the Front Range of Colorado. Doctoral dissertation, University of Colorado, Boulder, CO. 
LONEY, R.A. 1968. Flow structure and composition of the Southern Coulee, Mono Craters, California-a pumiceous rhyolite flow. Pages 415-440 in R.R. Coats, R.L. Hay, and C.A. Anderson, editors, Studies in volcanology: a memoir in honor of Howel Williams. The Geological Society of America, Inc., Memoir 116.

MacArthur, R.A., And L.C.H. Wang. 1973. Physiology of thermoregulation in the pika, Ochotona princeps. Canadian Journal of Zoology 51:11-16.

MacArthur, R.A., And L.C.H. Wang. 1974. Behavioral thermoregulation in the pika, Ochotona princeps: a field study using radio-telemetry. Canadian Journal of Zoology 52:353-358.

Manning, T., and J.C. Hagar. 2011. Use of nonalpine anthropogenic habitats by American pikas (Ochotona princeps) in western Oregon. Western North American Naturalist 71:106-112.

Massing, C.P. 2012. American pika (Ochotona princeps): persistence and activity patterns in a changing climate. Unpublished master's thesis, California Polytechnic State University, San Luis Obispo, CA.

Meaney, C. 1987. Cheek-gland odors in pikas (Ochotona princeps): discrimination of individuals and sex differences. Journal of Mammalogy 68:391-395.

Millar, C.I. 2011. Influences of domestic livestock grazing on American pika (Ochotona princeps) haypiling behavior in the eastern Sierra Nevada and Great Basin. Western North American Naturalist 71:425-430.

Millar, C.I., J.C. King, R.D. WestFall, H.A. Alden, and D.L. DELAny. 2006. Late Holocene forest dynamics, volcanism, and climate change at Whitewing Mountain and San Joaquin Ridge, Mono County, Sierra Nevada, CA, USA. Quaternary Research 66:273-287.

Millar, C.I., and R.D. Westfall. 2008. Rock glaciers and periglacial rock-ice features in the Sierra Nevada: classification, distribution, and climate relationships. Quaternary International 188:90-104.

Millar, C.I., and R.D. WestFall. 2010. Distribution and climatic relationships of the American pika (Ochotona princeps) in the Sierra Nevada and western Great Basin, U.S.A.; periglacial landforms as refugia in warming climates. Arctic, Antarctic, and Alpine Research 42:76-88.

Millar, C.I., R.D. Westfall, and D.L. Delany. 2013a. New records of marginal locations for American pika (Ochotona princeps) in the western Great Basin. Western North American Naturalist 73:457-476.

Millar, C.I., R.D. Westfall, and D.L. Delany. 2013b. Thermal and hydrologic attributes of rock glaciers and periglacial talus landforms: Sierra Nevada, California, USA. Quaternary International 310:169-180.

Millar, C.I., R.D. WestFall, and D.L. Delany. 2014. Thermal regimes and snowpack relations of periglacial talus slopes, Sierra Nevada, California, U.S.A. Arctic, Antarctic, and Alpine Research 46:483-504.

Millar, C.I., R.D. Westfall, and D.L. Delany. 2016. Thermal components of American pika habitathow does a small lagomorph encounter climate? Arctic, Antarctic, and Alpine Research 48:327-343.

MiLLAR, J.S. 1971. Breeding of the pika in relation to the environment. Doctoral dissertation, University of Alberta, Edmonton, Alberta, Canada.

MillaR, J.S. 1973. Evolution of litter-size in the pika, Ochotona princeps (Richardson). Evolution 27: 134-143.
Millar, J.S. 1974. Success of reproduction in pikas, Ochotona princeps (Richardson). Journal of Mammalogy 55:527-542.

Millar, J.S., AND F.C. ZwiCKel. 1972a. Determination of age, age structure, and mortality of the pika, Ochotona princeps (Richardson). Canadian Journal of Zoology 50:229-232.

Millar, J.S., AND F.C. Zwickel. 1972b. Characteristics and ecological significance of hay piles of pikas. Mammalia 36:657-667.

Moilanen, A., A.T. Smith, and I. Hanski. 1998. Longterm dynamics in a metapopulation of the American pika. American Naturalist 152:530-542.

Moyer-Horner, L., P.D. Mathewson, G.M. Jones, M.R. Kearney, And W.P. Porter. 2015. Modeling behavioral thermoregulation in a climate change sentinel. Ecology and Evolution 5:5810-5822.

Otto, H.W., J.A. Wilson, AND E.A. BeEver. 2015. Facing a changing world: thermal physiology of American pikas (Ochotona princeps). Western North American Naturalist 75:429-445.

Parmesan, C. 2006. Ecological and evolutionary responses to recent climate change. Annual Review of Ecology, Evolution and Systematics 37:637-669.

PeAcock, M.M. 1997. Determining natal dispersal patterns in a population of North American pikas (Ochotona princeps) using direct mark-resight and indirect genetic methods. Behavioral Ecology 8:340-350.

Peacock, M.M., AND A.T. SMith. 1997. The effect of habitat fragmentation on dispersal patterns, mating behavior, and genetic variation in a pika (Ochotona princeps) metapopulation. Oecologia 112:524-533.

RaY, C., AND E. BeEver. 2007. Distribution and abundance of the American pika (Ochotona princeps) within Lava Beds National Monument. Internal report to the USDI National Park Service. 62 pp.

Ray, C., E. Beever, and S. Loarie. 2012. Retreat of the American pika: up the mountain or into the void? Pages 245-270 in J.F. Brodie, E. Post, and D.F. Doak, editors, Wildlife conservation in a changing climate. University of Chicago Press, Chicago, IL.

Rodhouse, T.J., E.A. Beever, L.K. Garrett, K.M. Irvine, M.R. JefFress, M. Munts, and C. Ray. 2010. Distribution of American pikas in a low-elevation lava landscape: conservation implications from the range periphery. Journal of Mammalogy 91:1287-1299.

Rowe, K.C., K.M.C. Rowe, M.W. Tingley, M.S. KoO, J.L. Patton, C.J. Conroy, J.D. Perrine, S.R. Beissinger, AND C. Moritz. 2014. Spatially heterogeneous impact of climate change on small mammals of montane California. Proceedings Royal Society B 282. http://dx.doi.org/10.1098/rspb.2014.1857

Schwalm, D., C.W. Epps, T.J. Rodhouse, W.B. Monahan, J.A. Castillo, C. Ray, and M.R. Jeffress. 2016. Habitat availability and gene flow influence diverging local population trajectories under scenarios of climate change: a place-based model. Global Change Biology 22:1572-1584.

SEveraid, J.H. 1955. The natural history of the pikas (mammalian genus Ochotona). Doctoral dissertation, University of California, Berkeley, CA.

Sexton, J.H., J.P. McIntyre, A.L. Angert, and K.J. Rice. 2009. Evolution and ecology of species range limits. Annual Review of Ecology, Evolution, and Systematics 40:415-436.

Sgrò, C.M., A.J. Lowe, And A.A. Hoffmann. 2011. Building evolutionary resilience for conserving biodiversity 
under climate change. Evolutionary Applications 4: 326-337.

SHARP, P.L. 1973. Behavior of the pika (Ochotona princeps) in the Kananaskis region of Alberta. Master's thesis, University of Alberta, Edmonton, Alberta, Canada.

Shinderman, M. 2015. American pika in a low-elevation lava landscape: expanding the known distribution of a temperature-sensitive species. Ecology and Evolution 5:3666-3676.

Simpson, W.G. 2009. American pikas inhabit low-elevation sites outside the species' previously described bioclimatic envelope. Western North American Naturalist 69:243-250.

Smith, A.T. 1974a. The distribution and dispersal of pikas: influences of behavior and climate. Ecology 55: 1368-1376.

Smith, A.T. 1974b. The distribution and dispersal of pikas: consequences of insular population structure. Ecology 55:1112-1119.

Sмiтh, A.T. 1978. Comparative demography of pikas: effect of spatial and temporal age-specific mortality. Ecology 59:133-139.

SмITH, A.T. 1987. Population structure of pikas: dispersal versus philopatry. Pages 128-142 in B.D. ChepkoSade and Z.T. Halpin, editors, Mammalian dispersal patterns: the effects of social structure on population genetics. University of Chicago Press, Chicago, IL.

Smith, A.T., AND M. GiLPIN. 1997. Spatially correlated dynamics in a pika metapopulation. Pages 407-428 in I.A. Hanski and M.E. Gilpin, editors, Metapopulation biology: ecology, genetics, and evolution. Academic Press, New York, NY.

Smith, A.T., AND B.L. Ivins. 1983a. Colonization in a pika population: dispersal versus philopatry. Behavioral Ecology and Sociobiology 13:37-47.

SMITH, A.T., AND B.L. Ivins. 1983b. Reproductive tactics of pikas: why have two litters? Canadian Journal of Zoology 61:1551-1559.

SMith, A.T., AND B.L. Ivins. 1984. Spatial relationships and social organization in adult pikas: a facultatively monogamous mammal. Zeitschrift für Tierpsychologie 66:289-308.

Smith, A.T., AND B.L. Ivins. 1986. Territorial intrusions by pikas (Ochotona princeps) as a function of occupant activity. Animal Behaviour 34:392-397.

Smith, A.T., AND B.L. Ivins. 1987. Temporal separation between philopatric juvenile pikas and their parents limits behavioural conflict. Animal Behaviour 35: $1210-1214$.

Smith, A.T., W. Li, AND D. Hik. 2004. Pikas as harbingers of global warming. Species 41:4-5.

Smith, A.T., AND J.D. NAGY. 2015. Population resilience in an American pika (Ochotona princeps) metapopulation. Journal of Mammalogy 96:394-404.

Smith, A.T., AND M.L. Weston. 1990. Ochotona princeps. Mammalian Species 352:1-8.

SMith, J.A., AND L.P. ERB. 2013. Patterns of selective caching behavior of a generalist herbivore, the
American pika (Ochotona princeps). Arctic, Antarctic, and Alpine Research 45:396-403.

Sokolov, V.E., E. Eu. Ivanitskaya, V.V. Gruzdev, and V.G. HEPTNER. 2009. Lagomorphs [English translation of Russian text; A.T. Smith, scientific editor]. Smithsonian Institution Libraries, Washington, DC.

Stewart, J.A.E., J.D. Perrine, L.B. Nichols, J.H. Thorne, C.I. Millar, K.E. Goehring, C.P. Massing, and D.H. WRIGHT. 2015. Revisiting the past to foretell the future: summer temperature and habitat area predict pika extirpations in California. Journal of Biogeography 42:880-890.

Stewart, J.A.E., and D.H. Wright. 2012. Assessing persistence of the American pika at historic localities in California's northern Sierra Nevada. Wildlife Society Bulletin 36:759-764

Svendsen, G.E. 1979. Territoriality and behavior in a population of pikas (Ochotona princeps). Journal of Mammalogy 60:324-330.

TAPPER, S.C. 1973. The spatial organisation of pikas (Ochotona) and its effect on population recruitment. Doctoral dissertation, University of Alberta, Edmonton, Alberta, Canada.

VARnER, J.J., AND M.D. DEARING. 2014a. Dietary plasticity in pikas as a strategy for atypical resource landscapes. Journal of Mammalogy 95:72-81.

VARNeR, J.J., AND M.D. DEARING. 2014b. The importance of biologically relevant microclimates in habitat suitability assessments. PLOS ONE. http://dx.doi .org/10.1371/journal.pone.0104648

Varner, J., J.J. Horns, M.S. Lambert, E. Westberg, J.S. Ruff, K. Wolfenberger, E.A. Beever, and M.D. DEARING. 2016. Plastic pikas: behavioral flexibility in low-elevation pikas (Ochotona princeps). Behavioural Processes 125:63-71.

WEST, E.W. 1981. Adaptive patterns in the behavior of the Sierran pika, Ochotona princeps. Doctoral dissertation, University of California, Davis, CA.

Wilkening, J.L., C. Ray, E.A. Beever, and P.F. BrusSARD. 2011. Modeling contemporary range retraction in Great Basin pikas (Ochotona princeps) using data on microclimate and microhabitat. Quaternary International 235:77-88.

Wilkening, J.L., C. Ray, and J. Varner. 2015. Relating sub-surface ice features to physiological stress in a climate-sensitive mammal, the American pika (Ochotona princeps). PLOS ONE. http://dx.doi.org/ 10.1371/journal.pone.0119327

Yandow, L.H., A.D. Chalfoun, and D.F. Doak. 2015. Climate tolerances and habitat requirements jointly shape the elevational distribution of the American pika (Ochotona princeps), with implications for climate change effects. PLOS ONE. http://dx.doi.org/ 10.1371/journal.pone.0131082

Received 25 February 2016 Accepted 9 September 2016 